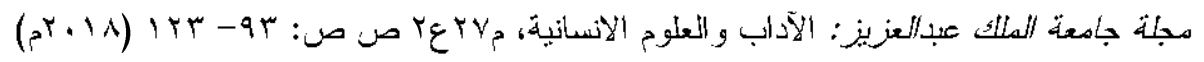

DOI:10.4197/Art.27-2.4

العنف ضد الفنيات: در اسة في العنف القائم على النوع الاجتماعي في المملكة العربية السعودية الاكتورة نورة بنت فرج المساعد جامعة الملك عبدالعزيز - قسم علم الاجتماع والخدمة الاجتماعية لردهية

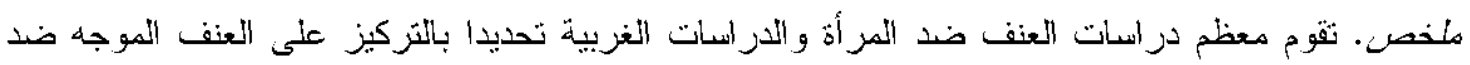

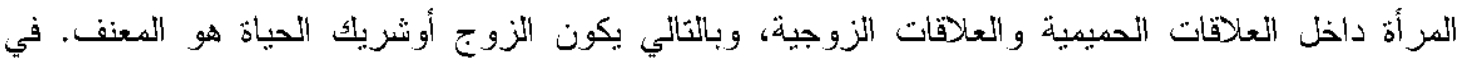

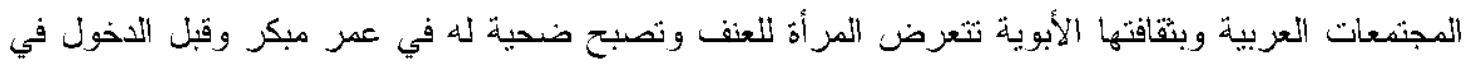

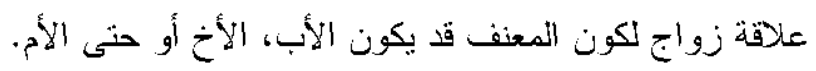

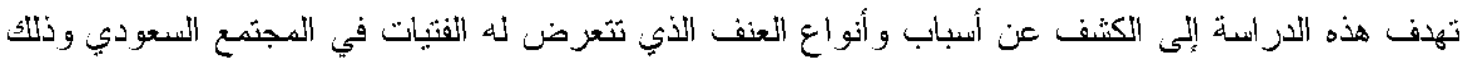

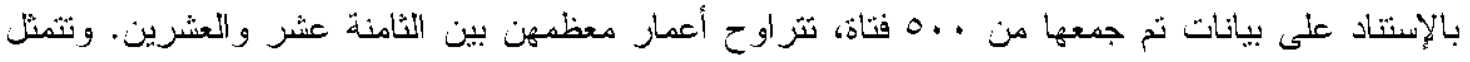

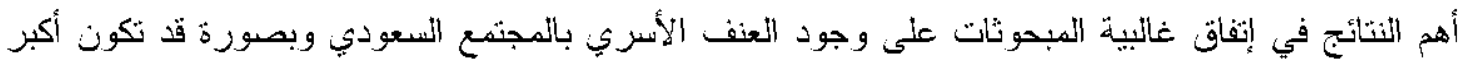

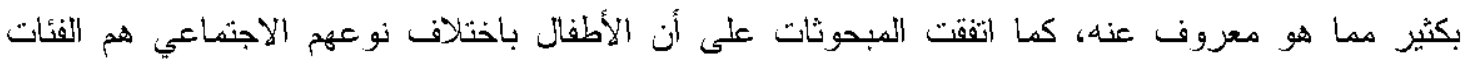

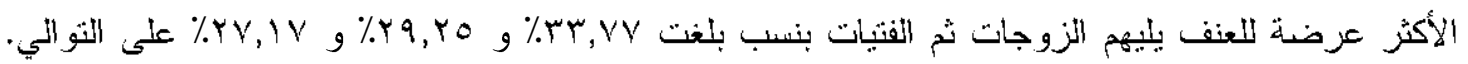

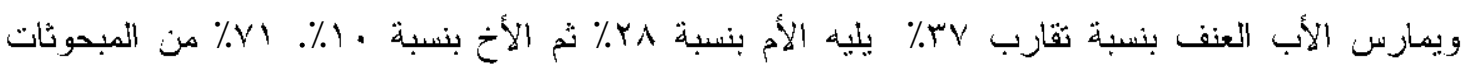

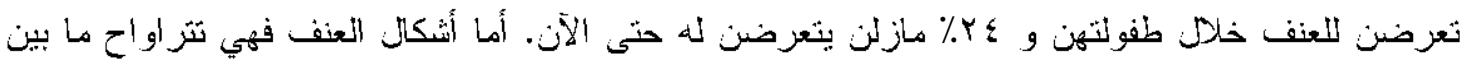

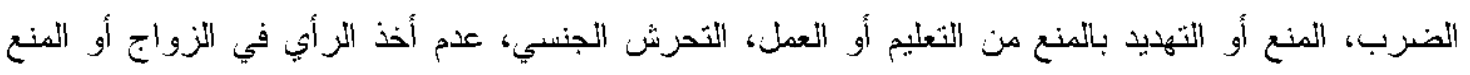

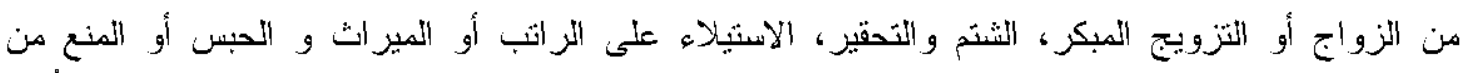

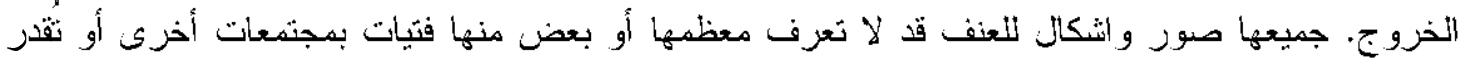

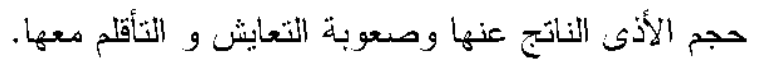
الكلمات الأفتتاحية: العنف ضد الطفل، العنف ضد المر أهة، العنف الأسري، العنف القائم على النوع الاجنماعي

(ץ.99) Gwen Hunnicutt الآن من تفسيرات ونقاشات ودراسات لم يصل بنا إلى نظرية نسوية تعمق من فهمنا لظاهرة العنف ضد المر أة. ومن هنا يتعرض مفهوم الأبوية للكثير

$$
\text { و العنف ضد الفنيات. }
$$

\section{المقدمة}

تستتد الكثير من دراسات العنف ضد المرأة على الزبط بين النظام الأبوي وخضوع العديد من النساء لسيطرة وعنف الرجل، إلا أن غوين هانيكت 
الرجال بمعنى لماذا فقط القليل من الرجال بستخدم العنف ضد المر أة في مجتمعات تتميز بالأبوية؟ من لرجب نتج عن النقد الذي تعرضت له الأبوية إلى إنحسار

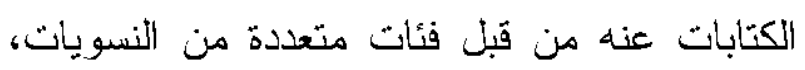

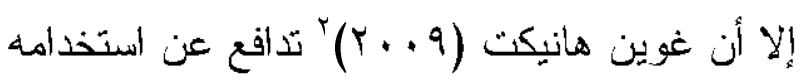
لتفسير العنف ضد المرأة من منطلقات تزى الأن

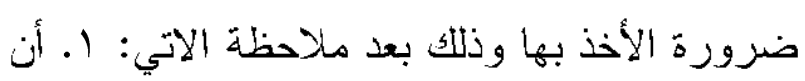
هناك تعددية في بناءات الأبوية أي أن الأبوية

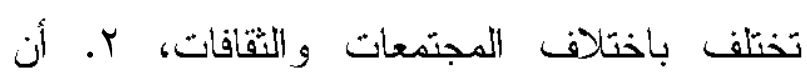
العنف الموحد من قبل الرجل ضد المرأة هو نتاج الأوضاع الهيكلية الاجتماعية. ولفهم سلوك الرجل فلرجل من الضروري الكثف عن الكيفية التي بقع بها الرجال في مخطط خاص بهم مُككن للهيمنة، يضاف إلى ذلك ان أي تحليل للأبوية لابد أن بدرك فئك

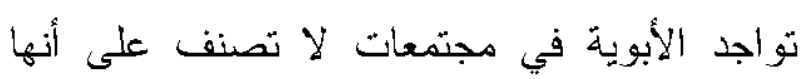

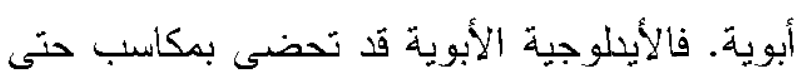

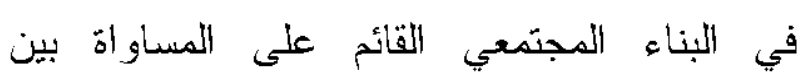
الجنسين. ولذلك فالمفهوم الأبوي بحاجة إلى نطويز يتزامن مع تطوير يطال النماذج الأخرى للتمايز

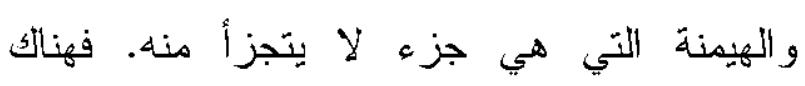
متاهات من تغيزات للقوى في النظام الأبوي

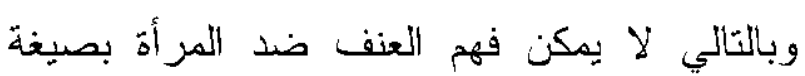
مبسطة قائمة على ظالم ومظلوم: بل يجب أن فئ

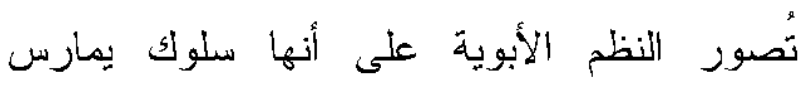

من النقد حتى أن بعض هذا النقا بطرح وجهة النظر القائمة على أن محاولات تشكيل الأبوية

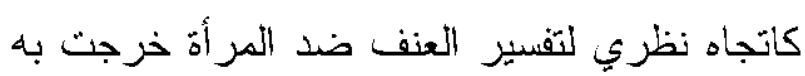

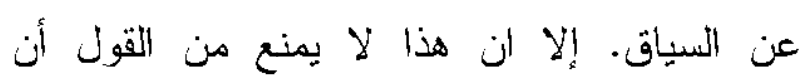
الأبوية كفهوم ذو أهمية خاصة في محاولة فهم يستحضر صور ونماذج التقسيم الهرمي بين الجنسين: وهما السيطرة وتقسيم القوة والتزتيبات

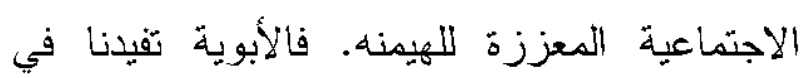

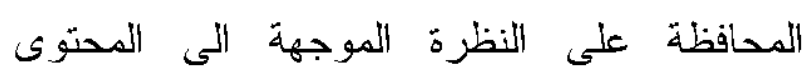
الاجنماعي عوضا عن تفسير العنف من منطلق ميل بعض الزجال للسيطرة.

ورغم أهمية المفهوم لكل ما سبق ذكره، إلا أن

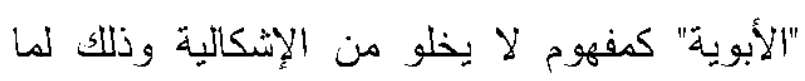
يحمله من موروثات تاريخية، ولذلك تعرضت الآنت الاراسات التي تربط بينه وبين العنف إلي العديد من الانتقادات أهمها أن المفهوم يبسط بين علاقات القوة، كما انه يوحي بعالمية خاطئة، حيث أن الطريقة التي نم بها استخدام الأبوية تجاهلت العديد من الاختلافات بين الزجال، وتعاملت مع الرجال كمجموعة منفردة منمائة في السمات و السلوكيات وبالتالي فالأبوية قد تقدم تقسير اللعنف الأي يمارسه الرجل ضد المر أة إلا انها لا بمكنها أن تقدم تفسير

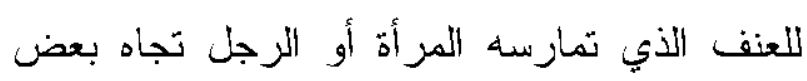


بأشكال و انو اع مختلفة من قبل الرجال و النساء على ربط مسبياته بالمحيط الاجتماعي المستقل عن الأفر اد. حد سو اء.

وبالمتالي هناك تو افق موازي بين النوع الاجتماعي

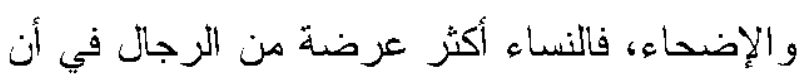
يصبحن ضحايا العنف داخل الزوراج، فعندما تتعزض المر أة للقتل فهي في الغالب تعرضت للقتل من قبل شريك الحياة، بعكس الرجل الذي حين يقع

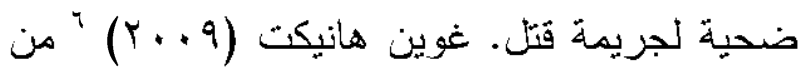
بيانات الإضحاء التي تستعرضها تظهر بشكل واضح ان العنف ضد المرأة هو نتاج نزتيبات اجتماعية، مما بعني أن هناك نموذج نمطي لإستهداف النساء وينميز عن نموذج الجماعات لهات

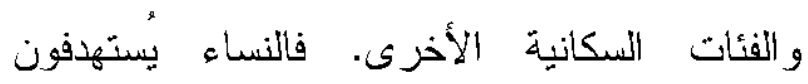
وبشكل أساسي بناءً على نو عهم الاجنماعي وحقيقة كون الرجال في كل بناء اجنماعي معنفين للنساء

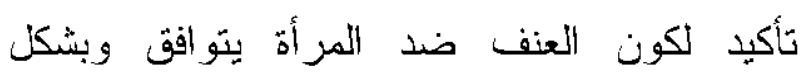
موازي مع النوع الاجنماعي. من هنا يصبح من

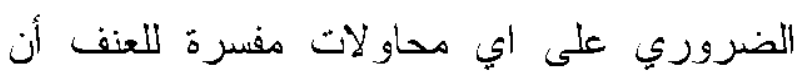
تتعامل مع حقيقة ارتباط العنف بالنوع الاجنماعي. النساء في الكثير من المجتمعات العربية والإسلامية لا يتمتعون بنفس المكانة الاجتماعي التي يتمتع بها

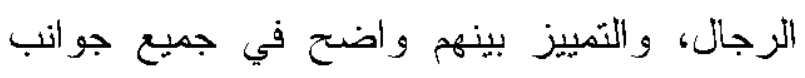

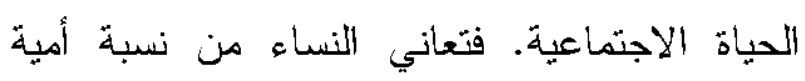
أعلى من الزجال، قيود على الحركة، صعوبة في الاجئه

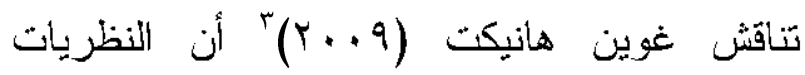
الاجنماعية المفسرة للعنف ضد المر أة إما انها ذات عمى جندري (لم تعطي النوع الاجنماعي حقه في

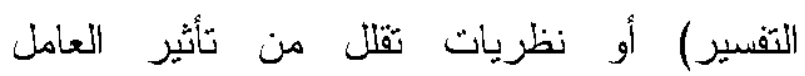
الجندري، وتقصد بذلك نظريات مثل نظرية الموارد (Resource) نظرية التبادل (Exchange) نظرية الضبط الاجتماعي (Social Control) ونظريات عنف الثقافات الفرعية ( Sub-Culture .(Violence بشكل عام بدأ الأتجاه نحو تفسير العنف الأسري في كتابات كل من موري ستراوس Murray Richard Straus Gelles العنف الأسري من ضمنها العنف ضد المرأة. إلا ان جوين هانيكت تزى قصور في تلك الكتابات المتمثل في أن تلك الكتابات ترى التسلط الذكوري ترى عامل مساهم وليس عامل محوري وأساسي في العنف ضد المرأة، في حين تزى الكتابات النسوية بأن النوع الاجنماعي هو الآليه الأساسية للاختلاف لرفي

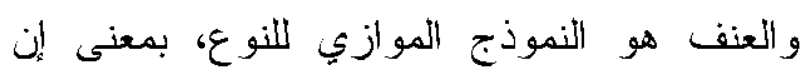
تفسير العنف لابد أن يبدأ بالتزتيبات الاجنماعية

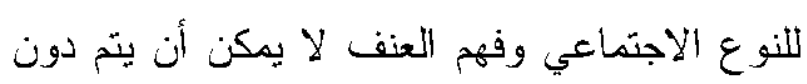


العام في معظم المجنمعات الأبوية يُعرض المرأة لمستويات مختلفة من الأبوية.

ويُرف العنف ضد المر أة بأي عمل بنتج عنه أذى بدني أو جنسي أو نفسي بما في ذلك التهديد بالقيام به أو الإكراه أو الحرمان التعسفي من الحرية سواء لاء حدث ذلك داخل الأسرة أو في المجتمع بصفه عامه. أما عن العنف القائم على النوع الاجتماعي فيمكن تعريفه على أنه "العنف القائم على الأدوار الاجتماعية التي يشكلها المجتمع بناء على الدور

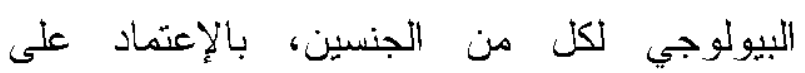
منظومة من القيم و الأعر اف و العادات و التثاليد التي بني ينتج عنها عدم مساو اة. ويشمل المصطلح: العنف

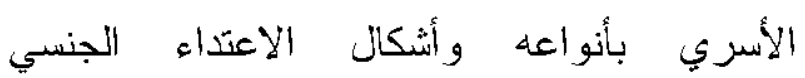
و الجسدي والممارسات الضارة مثل ختان البنات واختيار جنس المولود قبل التولادة و التفرقة في التزبية بين الأكور والإتاث كمظاهر لتدني القيمة

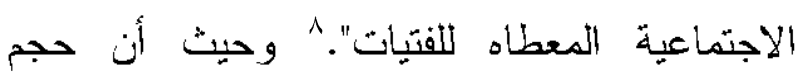
الار اسة لا يسمح باستعر اض تفصيلي لجميع أشكال

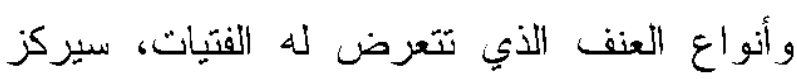
الجزء التالي من هذه الار اسة على أكثر اشكال

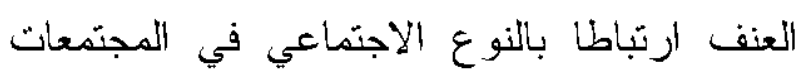

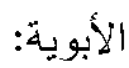
تنشئة الفتيات و التفرقة مع الأكور :
الوصول للخدمات الصحية، مشاركة بنسب أدنى في سوف العمل، النسبة الأعلى من العاطلين عن

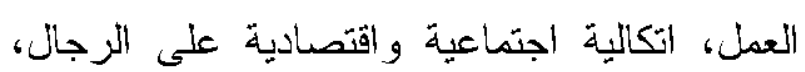
فصل بين المجال العام والخاص، مع خضوع للسلطة الاجتماعية الأبوية داخل الأسرة، القبيلة و المجنمع ككل.

وبسبب هذه المكانة الاجتماعية ترى نعيمة تبسم

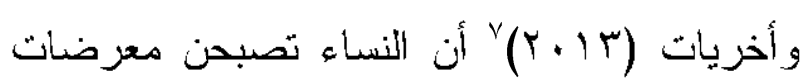

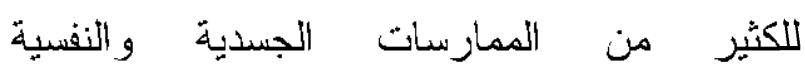
و الاجتماعية التي تجعل منهن ضحايا، كما أن هذه الممارسات في المقابل تشرعن للعديد من الجرائم التي ترنكب ضدهن كوسيلة لحماية ثيم وتقاليد

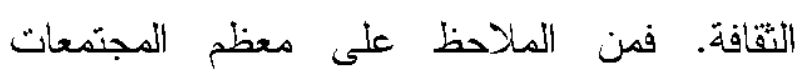
الاسلامية خضوع النساء للهيمنة و السلطة الذكورية داخل الأسرة وخارجها، فالفنيات في المكانة الأدنى

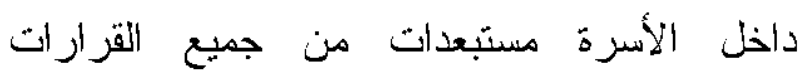
الأسرية والاجنماعية و الاقتصادية. كما أن التنشئة

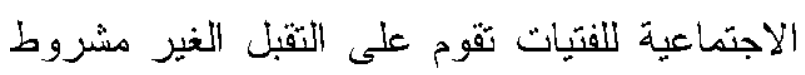

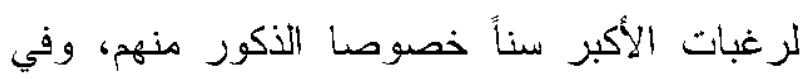
المقابل القرارات الخاصة بهن مثل التعليم، العمل التهل و التواجد في المجال العام هي حق لرب الأسرة

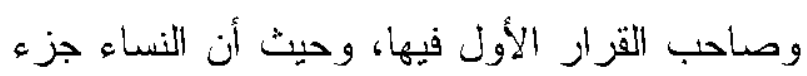
من مجتمع فهم أيضا بخضعون لقو انين هذا المجتمع وصن

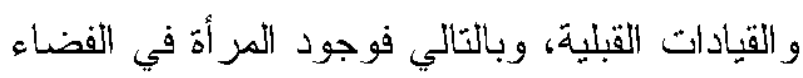


انخفضت بشكل حاد خلا العقد الخامس على التو الي وذلك حسب إحصاء 11 . ب.'. Sanaa Al تناقش سناء Harahsheh القائم على النوع الاجنماعي موجودة في أسر

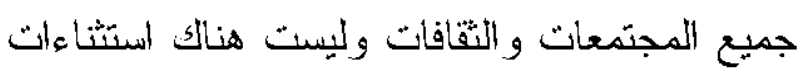

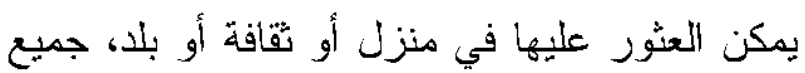

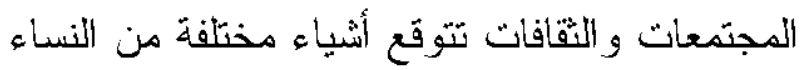

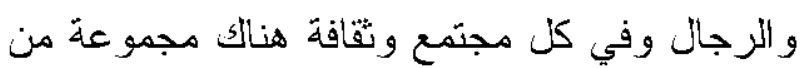

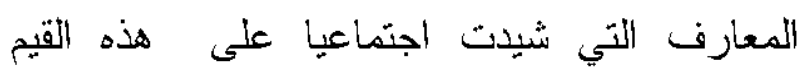

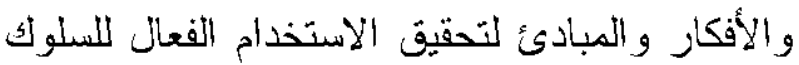

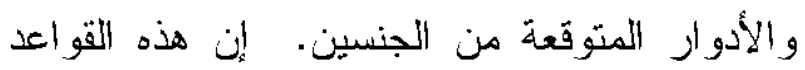
و المبادئ الموجهة خاصة تلاك المرتبطة بالمساواة بين الجنسين والدور الجنساني الأبي ينسبه المجتمع لأفراده ينت بناءه من خلا لاند عملية التنشئة

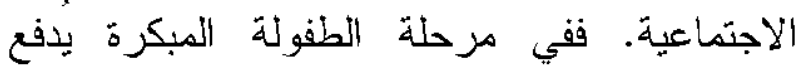

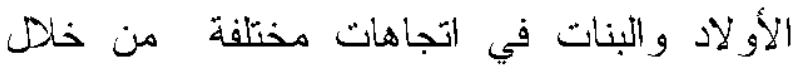
توقع سلوكيات مختلفة من الذكور والإناث. هذه هوله التوقعات تنتقل إلى الآباء و الأمهات اللذان يقدمان

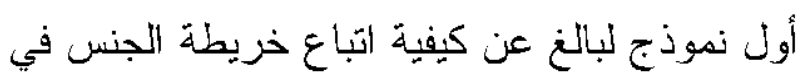
البيئة المنزلية. فالو الدين يعززان القو الب البهان النمطية الجنسانية بدون وعي منهما في كثير من الأحيان.

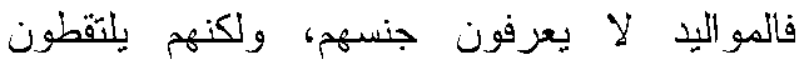
هويتهم الجنسية سريعا ويتعلمون أدوار الجنسين متأثرين في ذلك بو الديهم. ومن الو لادة يتم التعامل

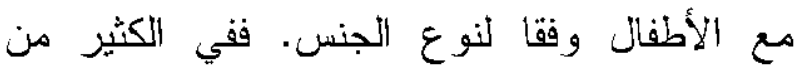

من الظواهز و القيم الثقافية الثابتة في المجتمعات الأبوية: تفضيل الأكور على الإناث، وهذا التفضيل يبدأ منذ لحظة الو لادة من حيث كون المولود ذكر لهر أم أنثى ولذلك تموت العديد من الفتبات حول العالم بسبب قيمتهم الإقل عن الأكور. تشير تقدير

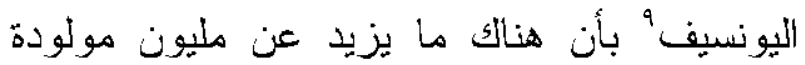
تموت سنويا بسبب قلة الزعاية الصحية و التغدية و الإهمال. في كل الثقافات تقريبا هناكك تفضيل

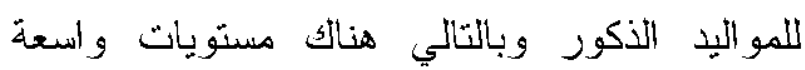
ومتعددة من الممارسات و الشعائر • في كل التقافات الأبن هو من بحمل اسم العائلة وهو بالتالي من هن

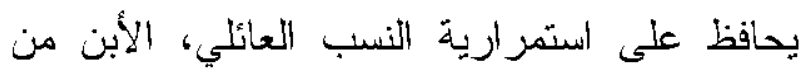
تقع عليه مسئولية العناية بأبويه ومن يملك حق أخذ الخديه

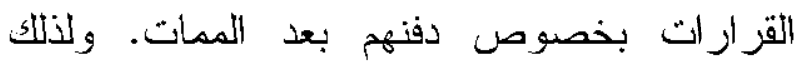
فالأسر التي لا تترك خلفها أبناء ذكور أكثر ما بعات يؤزق فكر ها هو إنقطاع نسلها وذكرها من الدنيا.

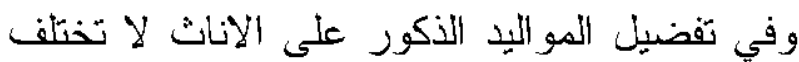

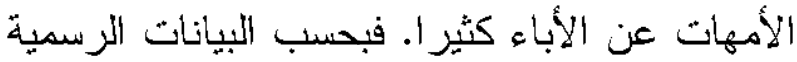
الهندية تفضيل الأكور على الإناث في الهند يودي لهي

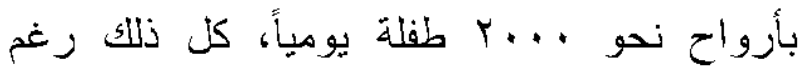

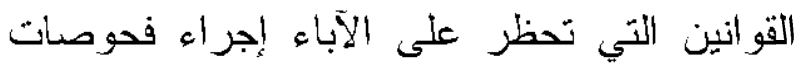
لمعرفة جنس الجنين أثناء الحمل، إلا أن عمليات الجاه

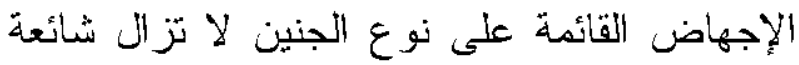

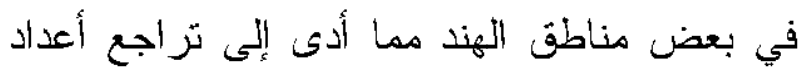

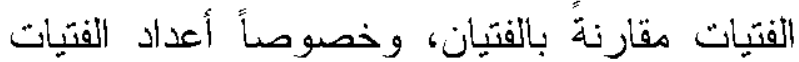
اللاتي تقل أعمازهن عن ست سنوات والتي 
تفاعلية، مثل أنشطة اللعب أو المساعدة في الو اجبات المنزلية وليس في التتظيف و التغذية التي تعنبر ضمن اختصاص الأم.

هنالك تفاعل واضح بين القيم الاجنماعية الثقافية و نوع الجنس و هذا ما جسده تعريف منظمة الأمم المتحدة للطفولة (الليونيسيف) في العام V. V. للتشئية الاجنماعية الجنسانية القائل بأنها: " العملية التي يتعلم التاس من خلالها التصرف بطريقة معينة، وكما تمليه المعتقدات المجتمعية، و القيم، و المو اقف، و الأمثلة. تبدأ التشتئة الاجنماعية بين الجنسين في وقت مبكر ومنذ أن تصبح المرأة حامل وذلك من خلا إصدار أحكام حول قيمة الأكور على الإناث. و وتستمر القو الب النمطية و التوقعات المختلفة للاكور والإناث من قبل أفر اد الأسرة و المعلمين و غير هم في المجتمع الأكبر" ".

تحدث التفرقة الجندرية كذلك في ثوزيع العمل المنزلي للأطفال. تقوم البنات بأعمال منزلية أكثر

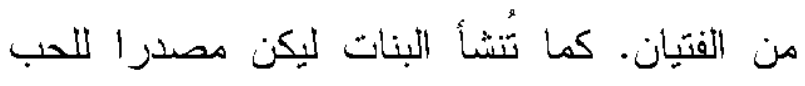
و الاعم العاطفي ولمرافقة أمهاتهن ومساعدتهن في

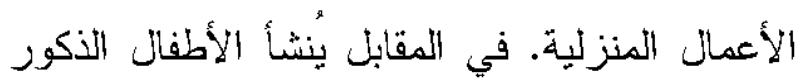
ليكونوا حماة لأخو اتهم و أقَاربهم ولمساعدة آبائهم على أداء واجباتهم. ومن هنا يمكن القول أن الكثير من قضايا النساء لها جذورها في مرحلة الطفولة، فعلى سبيل المثال استطاعت النساء حول العالم تحقيق العديد من الإنجازات إلا انها رغم ذلك لم
الثقافات يتعلم الأولاد التصرف مثل الرجال، في حين ينم تعليم الفتيات ليكن مهذبات ومعنمدات على الذكور ولهذه الفوارق الجنسانية تأثير الموسا على سلوك الزوجين في الحمل وحجم الأسرة، إن التفضيل

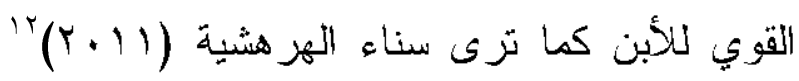
قد يؤثز على جهود الإنجاب الإضافية إذا لم يكن الأزواج سعداء بالتزكيبة الجنسانية لأسرتهم الحالية. وبشكل عام لا يقتصر تفضيل الأكور على أسر المجتمعات التقليدية حيث تظهر بعض Marleau \& Saucier الدراسات (مارلو وسويسيز 2002 )" تأثير اللأفضليات الجنسانية على سلوك الزوجين الإنجابي وحجم الأسرة النهائي حتى في البلدان الصناعية. ولا يقف الأمر عند هذا الحد فقط

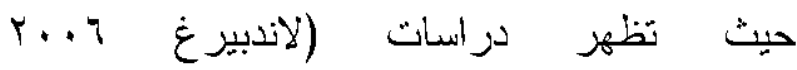
(lundberg من نوعية واستقزار الحياة التي يحظى بها الزوجين. فالو الدين الذين لديهج أبناء ذكور يتمتعون بدرجة عالية من الرضا الزو اجي و السعادة مقارنة بالّو الدين الأين لايهم اناث فقط. إن جنس الطفل يؤثر أيضا على الطرق التي يعامل بها الو الدين الأطفال، كيفية استثمار هم لوقتهج، و الأعمال المنزلية التي يقومون بها. الرجال يميلون إلى قضاء وقت أكبر مع الأبناء الأكور بينما تقضي النساء وقتا أطول مع البنات. و معظم الوقت الذي يقضيه الرجال مع أُطالهم هو في شكل أنشطة 
تحقق مساو اة مع الرجل، حيث ما زالت النساء يزتبط ارتباطا وثثقا في العديد من السياقات

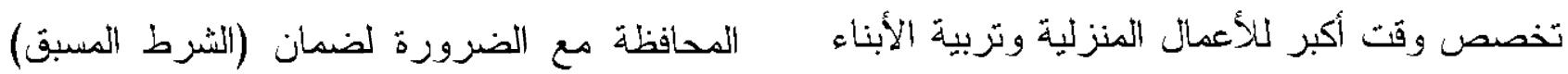

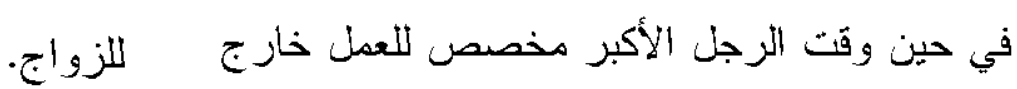

\section{الزواج المبكر:}

المنزل.

زواج الأطفال هو انتهاك لحقوف الإنسان سواء حدث لفتاة أو صبي، كما انه شكل من ألن أنكال الاعتداء الجنسي الذي تتعرض له الفتبات خصوصا في المجتمعات او التجمعات الفقيزة، ففي العديد من لاعن الدول لا تحضى الفتيات بفرصة اختيار متى ينت

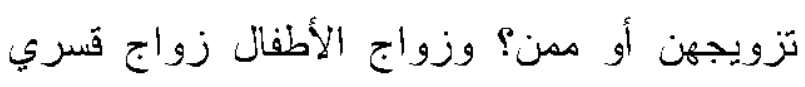
كما تعتبره الكثير من المنظمات و المو اثثي الدولية على اعتبار ان الطفل ليس لديه القدرة على اتخاذ

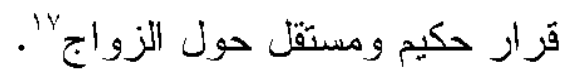

الزو اج من الفتبات في مقتبل العمر هو الممارسة الأكثر شيو عا في جنوب الصحر اء الكبرى بأفريقيا

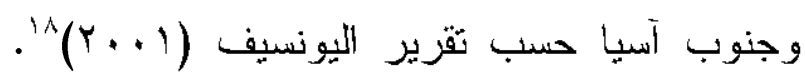
كما يحدث الزواج بالصغيرات حسب التقرير في مناطق مثل النشرق الأوسط، شمال أفريقيا وأجزاء أخرى من آسيا، والزواج في سن البلوغ أو بعده بقليل هو شائع بين أولئك الذين يعيشون أنماط الحياة التقليدية ولذلك بحدث أيضا في أجزاء من بن بن غرب وشرق أفريقيا وجنوب آسيا حيث الزيجات في وقت سابق بكثير من البلوغ ليست غير عادية،

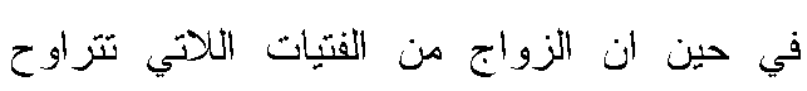

عُرفت آن أوكلي (19VY) بصياغة مصطلح التنشئة الاجنماعية للجنسين الأي وله

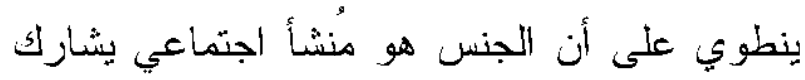

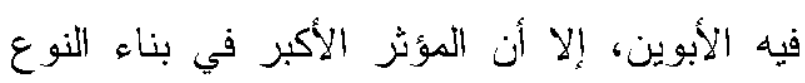

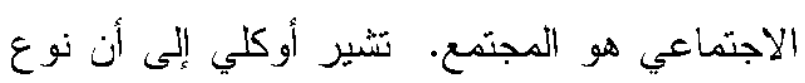

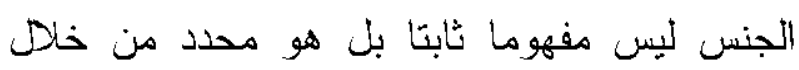

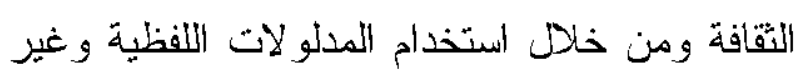

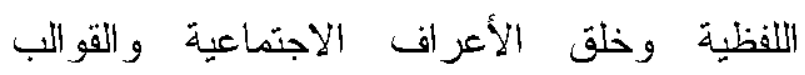
الندطية التي تحدد السلوك السليم و المقبول. يليها

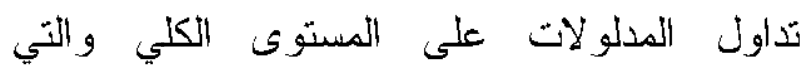
تعززها وسائل الإعلام، وعلى المستوى الجزئي

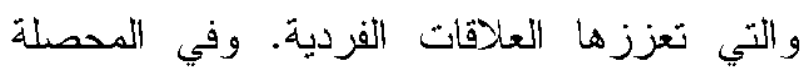
اللهائية يدخل المفهوم المعجم السائد في العلاقات بين الجنسين وديناميات التنمية.

هناكك تفاعل واضح كما تزى أوكلي بين القيم الاجنماعية الثقافية مع التنشئة الاجتماعية بين الجنسين. وهو ما بفسر جزئيا فقط، أولوية مستمرة

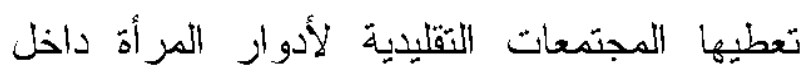
اطار الأسرة وواجباتها على الأدوار العامة. وتُّمج معظم الفنيات الصغيرات في "الحتمية البيولوجية" لدورهن المستقبلي اجنماعيا بوصفهن أمهات الذي بي 
الذي يجب مناهضته، فالزواج المبكر للفتيات يتسبب في محدودية الفرص التي تنيح تطوير الذات، و على درجة التحصيل العلمي للفنيات وبالتالي إضعاف قدر اتهن على المنافسة في سوق درفي العمل. ويعتبر التسرب من التعليم أكثر وأهم نتائج

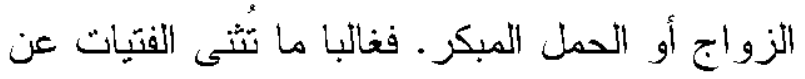
الذهاب إلى المدرسة عندما يتزوجن أو قد يُطردن الزئل

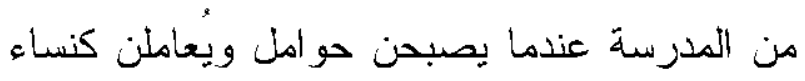
بالغات بغض النظر عن أعمارهن. وتأتي أهمية

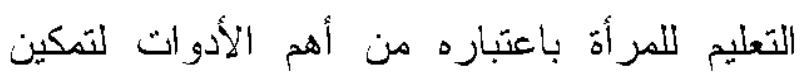
النساء في المجتمع ومن أهم الحقوق التي يؤدي الهي التئي الاستثمار فيها لتغييز اللواقع الاجنماعي والثتافي السائد الذي بنظر للمر أة نظرة تقليدية ويحول دون الأني الارتقاء بوضعها. أن فرص النساء في إيجاد عمل لهل

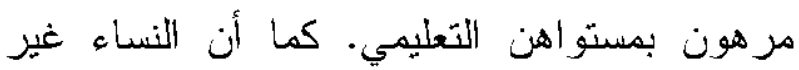
المتعلمات هن أكثر عرضة لفقدان العمل بالمقارنة

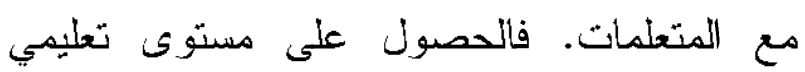

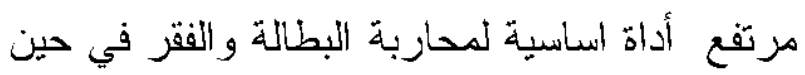
أن زواج الصغير ات سيرتبط به إنخفاض مستو اهن العلمي والذي بدوره سيحد من فرص حصولهن على العمل والأمن الاقتصادي والمو ارد الاجتماعية والاقتصادية و المشاركة في اتخاذ القزار دالخل

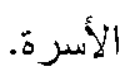

العلاقة بين الفقر والزواج معقدة وذات ابعاد متعددة، فليس الفقز إحدى أسباب الزواج المبكر

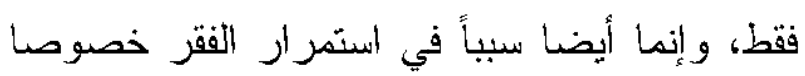

أعمار هن بين 17 و 11 أسنة شائع في أجز اء من أمريكا اللاتينية وفي الجنوب من أوروبا النشرقية. بشكل عام هنالك نقص كبير في المعلومات المتاحة عن مدى انتشار زواج الصغيرات ويرجع ذلك إلى أن الكثير منه غير مسجل وغير رسمي وتلعب

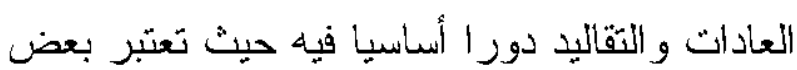

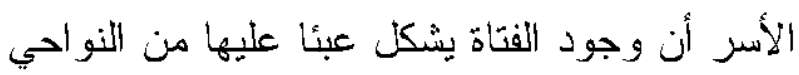
المادية والاجتماعية، وأن تزويجها المبكر فيه محافظة عليها وسترها و وعلى شرف العائلة.

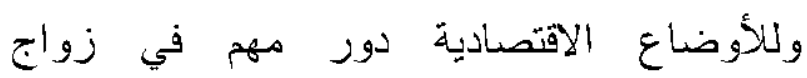
الصغيرات، حيث يميل بعض الفقزاء إلى تزويج بناتهم في سن مبكرة للتخفيف من المصاريف

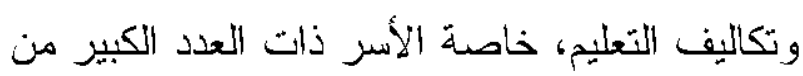
الاطفال وذات الاخول المنخفضة، فالحالة الاقتصادية ومستوى الفقز للأسرة سبب للجوء

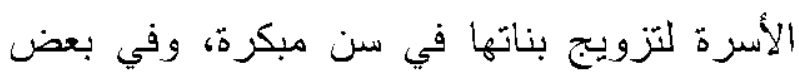
الحالات يرتبط الفقز بالجشع حيث تزوب الصغيرات بهدف الاستفادة من مهر هن أو التخلص برليط من مسئوليتهن كما يرتبط في بعض الثقافات مهر الفتاة بعمر ها وبالتّالي كلما قل عمر الفتاة كلما زاد مهزها أو قل المهر الذبي يُدفع للعريس كما يحدث في بعض المجتمعات. تؤكد العديد من الدراسات و التقاريز 19 على اعتبار الزواج المبكر شكل من أشكال العنف ضد الفر الفنيات 
تزويج الفتاة من عائلة "جيدة" يقوي من الزوابط

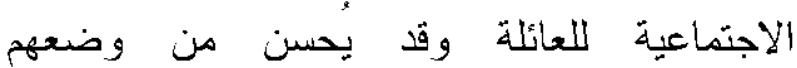
الاجتماعي أيضاً. كما تعتقد الأسر أيضا أن الزواج المبكر للفتيات يحميهم من الاغتصاب في مناطق الصراعات و الحروب ومن النشاط الجنسي قبل الزواج و الحمل ومن الأمراض مثل فيروس نقص ومس المناعة البشرية و الإيدز.

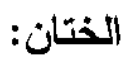

تشويه الأعضاء التتاسلية للإناث أو ما يعرف بالختان ممارسة تقليدية يمكن أن تكون لها تبعات خطيرة على الصحة بالإضافة إلى ما تسببه من الآم ومعاناة ولذلك هي إحدى صور العنف ضد الفنيات لأنها انتهاك من الحقوق الانسانية المقبولة دوليا. تستتد المجتمعات الممارسة لختان الإناث على لهن مرجعيات ثقافية، اجنماعية و اقتصادية، ولكن من منظور حقوقي انساني، تعكس هذه الممارسة عدم مساو اة متجذرة بين الجنسين وشكل منطرف من أشكال التمييز ضد المرأة. ولكون هذه الممارسة كما تز اها منظمة الصحة العالمية'r انتهاكا لحقوق

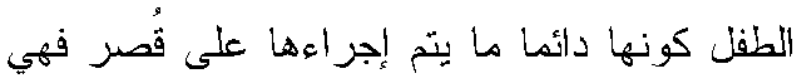
بالتالي تمثل انتهاك لحق الفتاة في الصحة والأمن و السلامة البدنية، و الحق في عدم التعرض للتعذيب

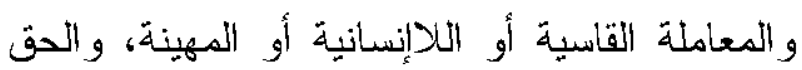
في الحياة عندما تؤدي الممارسة إلى الوفاه. وتقدر
حين تصبح تلثك الفتيات عائلات لأسرهن في حالات الطلاق أو التزمل ومن هنا يأتي ربط الدراسات ‘r بين الزواج المبكر وتأنيث الفقر في العديد من الدول النامية. الفقز هو أحد العوامل التئيسية التي يقوم عليها الزوواج المبكر، وبالتالي تزوج الصغيرات للتخلص من عبئهن الاقتصادي برجل أكبر منهن سناً أو برجل كبيز في السن وهذا ما يجعله ليس مجرد زواج و إنما استراتيجية للبقاء على قيد الحياة لأسرة كاملة. في دراسة نوال نول نور

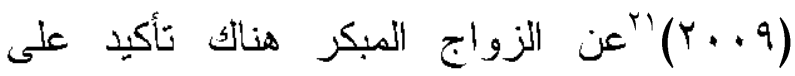
العلاقة بين الحاجة والزواج المبكر إلى جانب

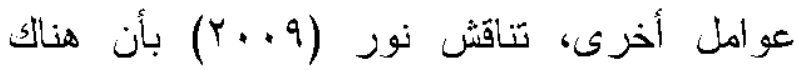
ثلاث عوامل أساسية تدفع لزواج الأطفال وهي: الفقز، الحاجة إلى تعزيز الزوابط الاجتماعية والايمان إن التزويج المبكر للفتيات هو حماية لهن. يحقق التزويج المبكر للفتيات في المناطق الفقيرة قيمتان اقتصاديتان، الأولى هو ضمان الأسرة

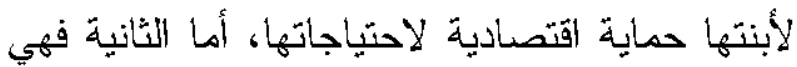
إن تزويج الفتاة يخفف من عبئها الاقتصادي على أسرتها. زواج الأطفال هو أولا وقبل كل شيء نتاج حاجة اقتصادية محضة، الفتيات مكلفات اقتصادياً فهن بحاجة للطعام، للملبس ولللتقيف، وفي نهاية المطاف سيتزكن بيت الأسرة لبيت الزوجية ولكنهن قبل ذلك سيجلبن مهر لأسرهن. كما أن 
من كل من الرجال و النساء في المجتمع المحلي

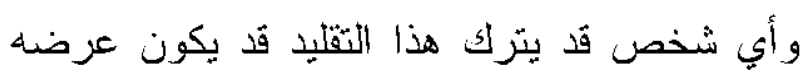
للإدانة و النبذ، وبالتالي يصبح ختان الإناث اتفاق

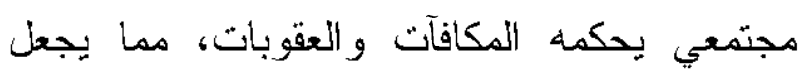

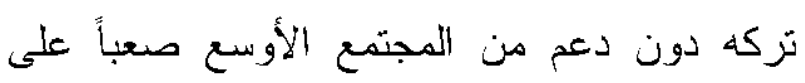

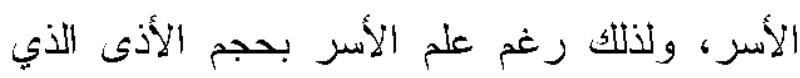

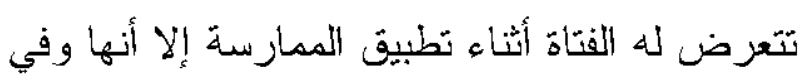
نظر هم تحقق فو ائد أعلى مدا تحققه من خسائر أو لون سلبيات. يحدث ختان البنات كما تز اه منظمة الصحة العالمية (2010) نتيجة خليط من العوامل الثقافية والاجتماعية، ولذلك يشترك أعضاء الأسرة الممتكة في قزار ختان الإناث وتتولى النساء التزتيبات المصاحبة للممارسة والاحتفال بها حيث يعتبر لإن ختان الإنات ضرورة اجتماعية لتتشئة الفتيات وتزويجهن بحس الموروث الثقافي لهذه المجتمعات. عند الزواج يتوقع الرجل الزواج

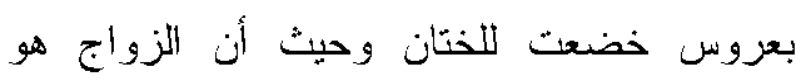
ضرورة اجتماعية و اقتصادية يصبح استمرار الختان ضرورة اجتماعية و اقتصادية كذلك. فالختان يجعل من الفتاة الزوجة "المناسبة" لضمانه لعذريتها. من هنا تقوم الأمهات في كثير من

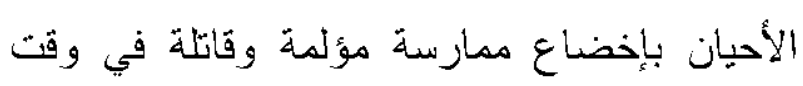

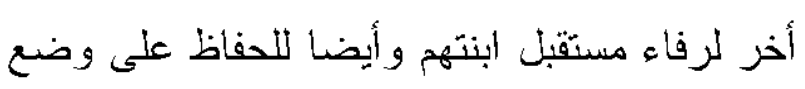

منظمة الصحة العالمية (9 . . ب) بأن ما بين . . 1-

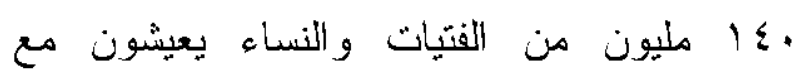
عو اقب الختان وإن هناك ب مليون فتاة في افريقيا تحت خطر التعرض لإجراء الختان عليها سنوياً. نم توثيق ممارسة ختان الإناث أو كما تطلق عليه منظمة الصحة العالمية "تشوية الأعضاء التناسلية

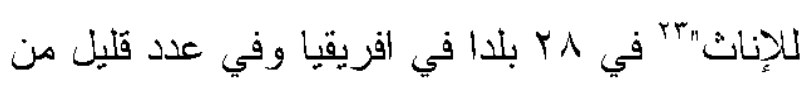

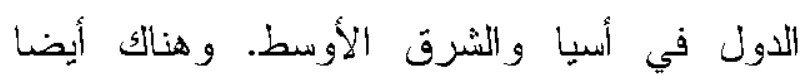
بعض أشكال لختان الإناث نم رصدها من قبل

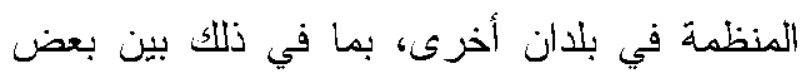
المجموعات العرقية في أمريكا الوسطى و الجنوبية. وقد أدى تزايد الهجرة إلى زيادة عدد الفنبات و النساء التلاتي يعشن خارج بلدهن الأصلي

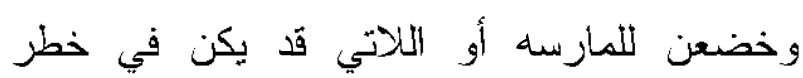
التعرض لها. ويختلف العمر الأي تخضع فيه الإناث لعمليات الختان وذللك بحسب التقاليد و الظروف المحلية، إلا أن معظم الإناث بخصعن

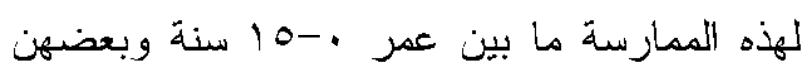
في سن أكبر أو كمتزوجات. مأ لين

تعكس هذه الممارسة سيطرة المجتمع على المر أة وعدم التكافؤ بين الجنسين،، ولذلك تربط دراسة اليونسيف (2005)؛ بين قدرة النساء على ممارسة السيطرة على حياتها و أعتقادهن بأن ختان الإناث ممارسة يجب أن تتنهي. ويلقى ختان الإنات الدعم 
ينظر إليه أيضا على أنه ممارسة لزيادة الخصوبة

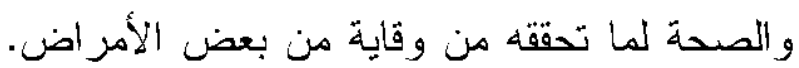
وهناك أيضا القيم الجمالية المعنية بالثقافة: امرأة مختته في ثقافة المجتمع ليست طبيعية فقط ولكنها

جميلة.

رغم كل ما سبق، الختّان هو شكل من أنشكال العنف ضد المرأة حيث وتقت منظمة الصحة العالمية2008 ^^ب بعض الآثار المتزتبة على الختّان على صحة النساء والفنيات. وشمل ذلك الموت الأني يمكن أن يقع بسبب قوة النزيف. الألم اللثديد الأي بسيبه قطع أجزاء من الجسم. الإجهاد والصدمة الناجمة عن ما تمر به الفتاة، العدوى الحادة التي يمكن أن تحدث بسبب الأدوات المستخدمة. كما تثمل الآثار إصابة اعضاء أخرى بالجسم بنزيف حاد، الآم عند الجماع، و المضاعفات في المخاض و صعوبة في الو لادة. وكما أظهرت

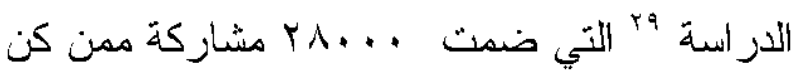
ضحايا لنشويه الأعضاء التتاسلية ان المخاطر العالية للعطليات القيصرية و النزيف بعد الولادة تكون أعلى بين النساء اللواتي تم خضوعهن للختان. ورغم ملاحظة منظمة الصحة العالمية (2012) بr بوجود تغيير في ممارسة ختان البنات كنتيجة للجهود الدولية للمنظمات الحقوقية

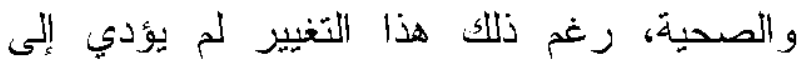

هذه الابنه الخاص داخل الأسرة والمجتمع. فكما

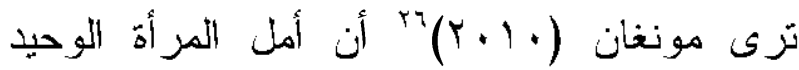
لالبقاء في مجتمع لا تملكك فيه اي موارد اقتصادية هي أن تكون متزوجة.

ويرتبط ختان الإناث بقضايا التقليد والاستمرارية الأقافية أيضا، كما يضمن التقليد المستمر سبل العيش للختان. الختان هو عمل يؤكد الهوية الثقافية والأثثية للمجنمع عن طريق وضع علامات على للى جسم أعضاء المجتمع. ختان الإناث هو أيضا في كثير من الأحيان حول القبول الاجتماعي، فالختّان علامة على النضج الجنسي، وفتاة تصبح امر أَّد". وتختلف المجتمعات في تبريزها لممارسة الختان، فكما سبق ترى بعض التقافات أن نقطة الختان هي نقطة نحويل الفتاة إلى انثى من خلال إزالة أجزاء جسمها التي تجعلها ذكوربة. في هذا الحالة، الختان هو رمز هوية المرأة الأنثوية و المر أة المختته هي في المالة امرأة طبيعية في مجتمعها في حين تزى تقافات أخرى في الختان دليل على الاحترام ومن هنا يصبح شرط أساسي للتككن من الزواج. كما تنتقدة

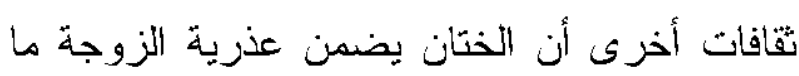

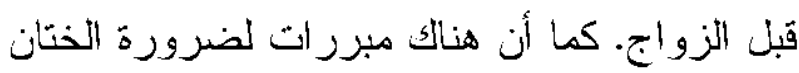

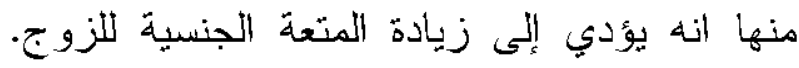
وفي العديد من المناطق بعتبر الختان ممارسة لتنقية الأعضاء التتانلية "غير النظيفة". ختان الإناث 
القضاء على الممارسة ككل ولكن من ناحية بدأت القتل المبنية على ادعاءات، إثاعات، ظنون أو

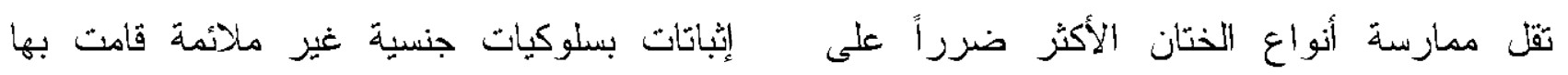
المر أة ومن ناحية أخرى بدأت الأمهات في تطبيق الضحية. ويضم مجلس العائلة الأب، الأخوة

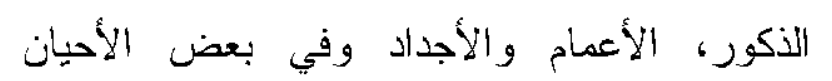
هذه الممارسة لاى طبيب منخصص.

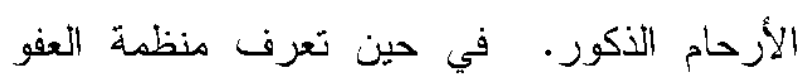

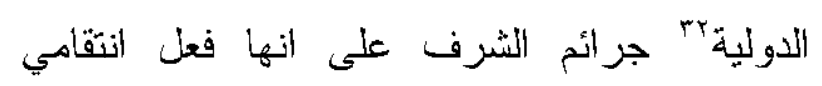
يصل إلى حد القتل برتكبه احد الذكور في العائلة ضد الزوجات و الأخوات و اللبنات و والأمهات لاتهامهن بجلب العار على الأسرة.

وتستهدف جرائم الشرف أفعال مختلفة من الاناث

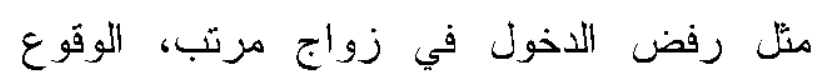

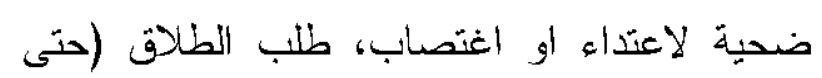
لو كان من زو جيء) او لمز اعم حقيقية أو مشتبه

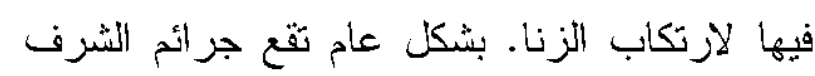

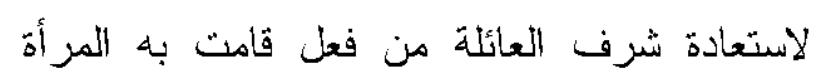

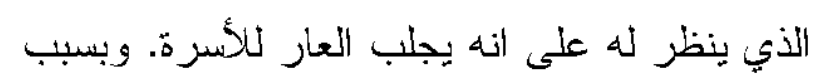

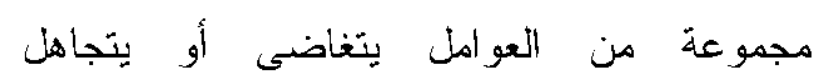
المسؤولون في الكثير من الأحيان عن استخدام

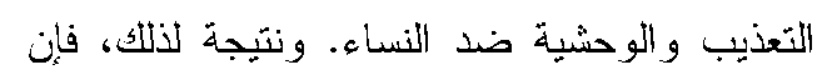

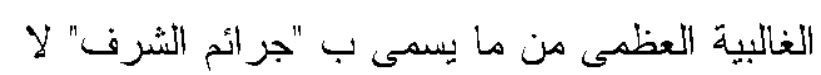

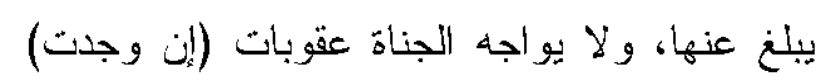
حقيقة" ويرجع ذلك لكون القانون ينظر لها ضمن ولاهن ما يطلق عليه "جر ائم العاطفة" ويقصد بها تحويل يرتبط شرف الأكور في العائلة في العديد من المجتمعات التقليدية بجسد نساء العائلة، ولحماية هذا الشرف يقوم الرجال بتنظيم وتوجيه جنسانية النساء وحريتهن في ممارسة اي سلطة على خيار اتهن في

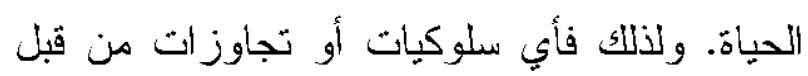
المرأة للخروج عن هذه التزتيبات العائلية أو تحدي لسلطة ذكور العائلة يتطلب عقوبة ليس لهذه التجاوزات فقط و إنما لاستعادة الشرف المفقود وتأكيد لهيمنة الذكور في العائلة داخل الأسرة و و المجتمع.

استطاع المؤتمر العالمي الترابع للمرأة في بكين (1990) ان يسلط الضوء على اشكال منعددة

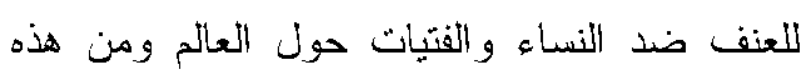
الاشكال جرائم الشرف التي تعرفها كل من ايسان

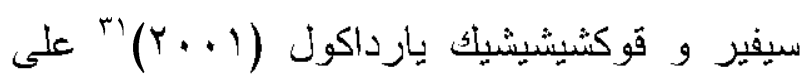
انها ذلك المصطلح العام الذي يشير للقتل العمد لطفلة، مر اهقة أو امر أة بالغة من قبل و احد أو أكثر من ذكور أسرتها النووية أو الممتذة. هذا القتل الأي مني يتم تتفيذه عندما يقرر مجلس العائلة زمن وطريقة 
الجريمة بالتزكيز على مشاعر الجاني والأسباب الأبوية الاتقليدية مهددة ويقصد بذلك ان تكون الجماعة الابوية أقلية داخل مجتمع كبير لا نشترك ولك التي دفعته لازتكاب الجريمة. مع الجماعة الأقلية في مفاهيم كالشرف والآراء حول أدوار الجنسين.

وعلى الزرغم من صعوبة الحصول على معلومات إحصائية ذات مغزى عن عدد حالات القتل بدافع الثرف التي تحدث سنويا في أي مجتمع معين إلا انه يقدر عالميا بأن هناك ... . م فتاة و امر أة يقتلن كل سنة من قبل أفراد الأسرة الأكور من أجل الشرف. على مسنوى العالم تلثين الضحايا يتم قتلهح على يد أسرهم، ويشكل القتل من قبل الأسرة

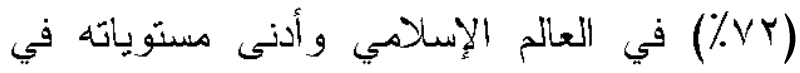

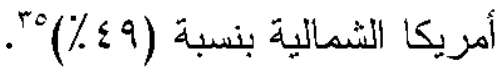

إن الطبيعة المميزة لجرائم "الشرف"، و التي تمييزها عن أشكال أخرى من العنف المنزلي هو الطبيعة الجماعية للجزيمة، حيث العديد من أعضاء الأسرة والأسرة الممتدة تتآمر على الفعل بشكل رسمي ومنظم وتقوم به إما بشكل مباشر أو بالتتسيق.

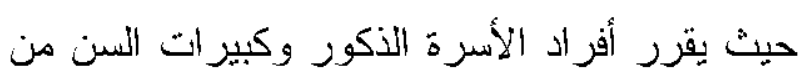
اللنساء ما إذا كان ينبغي قتل امرأة و الععل على لئل

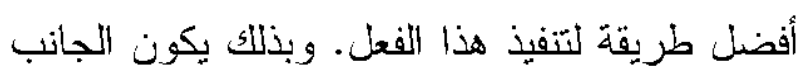
الجماعي و العائلي لجز ائم الشُرف هي واحدة دن

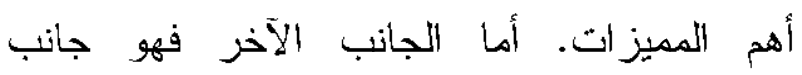

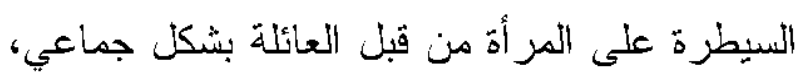
غالبا ما بعتقد القتل الشرف خطأ بأنه ممارسة إسلامية أو ممارسة يتغاضى عنها الإسلام لكونه غالبا ما يحدث في المجتمعات ذات الأغلبية المسلمة. في الواقع الفعلي تحظر جر ائم الثرف في الإسلام و لا يوجد ذكر لهذه الممارسة في القرآن أو لو في الحديث. كما أن هنالك أدلة قليلة على الممارسة في الأغلبية المسلمة في بلدان مثل إندونيسيا أو هل ماليزيا. في الحقيقة تحدث جرائم الشرف في باني مجتمعات ذات ابوية قوية أو في مجنمعات تؤمن بالشرف والتي توجد أساسا في الشرق الأوسط، البلقان، جنوب البحر المتوسط، وجنوب آسبا حيث الأسرة أو الأقارب هم المجموعة الأساسية الاجتماعية و الاقتصادية و السياسية. إن بقاء واستمر ارية جرائم اللشرف بعتمد بشكل

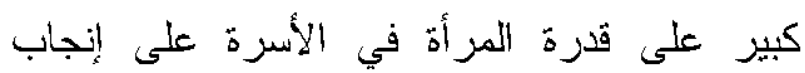
اطفال شُرعين، ومن هنا ينم التركيز على جنسانية

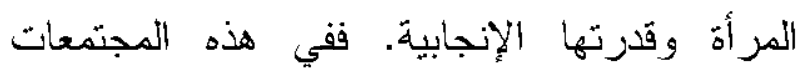

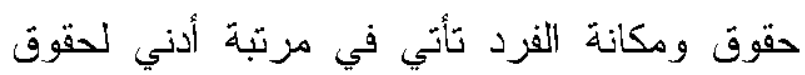

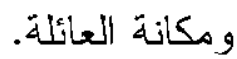

وتفنزض دراسة جين هايلي (2007)؛ زيادة حالات القتل بدافع الثرف في الحالات الاقتصادية و الأزمات أو النزاعات، أو حيث تكون سلطة القيم 
على موقف الجنسين من جرائم الشرف أن غالبية الرجال و النساء يؤيدون ممارسة القتل للشرف إذا هرأ

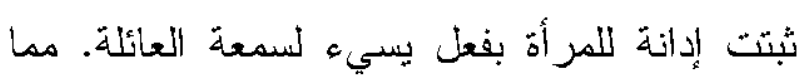
يؤكد على قوة قيمة الشرف وعدم تأثر العقلية التقليدية بالتعليم.

أهداف الأدراسة: 1.التعرف على وجهة نظر الفتيات في ظاهرة العنف الأسري في المجنمع. r. التعرف على مدى انتتار ظاهرة العنف بين الفتيات. r. التعرف على أنواع وأشكال العنف الذي تتعرض له الفتاة على يد الأب، الأم والأخ.

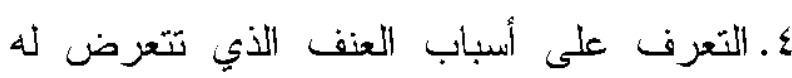
الفتاة على يد الأب، الأم والأخ. ه. التعرف على موقف الفتيات من تدخل الجهات الرسمية لحماية الفتيات من العنف الأسري.

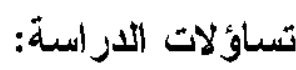

1. ماهي وجهة نظر الفتيات في ظاهرة العنف

$$
\text { الأسري في المجتمع؟ ماهي وجن }
$$

r. ما مدى انتشار ظاهرة العنف بين الفتيات؟

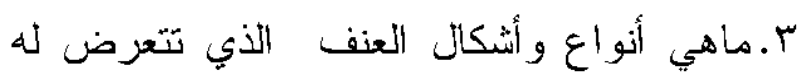

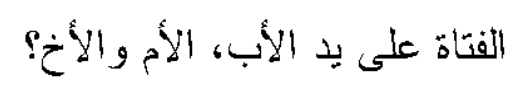

ع.ماهي أسباب العنف الذي تتعرض له الفتاة على الدى

$$
\text { بد الأب، الأم والأخ. }
$$

حيث يعتقد ان أي فشل في الامتثال لقو اعد المجتمع

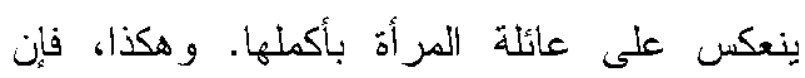

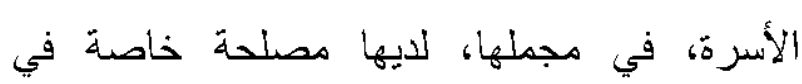

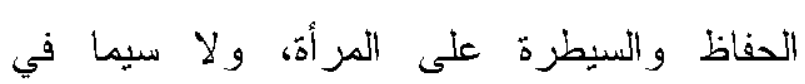
المجنمعات الأبوية المتشددة.

من وجهة النظر الاجتماعية، يختلف العلماء في نظرتهم حول تأثير التحديث على بعض الممارسات اللقافية، وبالتالي يدعم البعض التغير ات التقافية ويعتقدون بأنها نتيجة للتغيرات التي تحدث في العالم بسبب التقدم الاقتصادي و التحديث؛ في حين يرى البعض بأن للقيم التقافة تأثير مستقل على الثى العالم، ولا يزال إيمان الناس بها وتتم ممارستها، وبالتالي تقف هذه الممارسة صامدة امام عمليات التحديث التي يمر بها المجنمع وبّال. وفيما يتعلق بتأثير التعليم على تغيير بعض القيم التقافية ومنها جرائم الشرف، تظهر الار اسات نتائج متناقضة من حيث تأكبد للتأثير الايجابي للتعليم على تغيير عقلية الاقراد تجاه بعض الممارسات

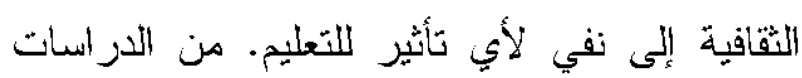

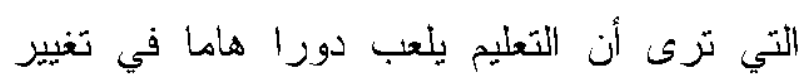
عقلية الناس، دراسة بحثية في الأردن التي أكدت لرت لهات على أن حقوف النساء تجد دعما أكبر من قبل

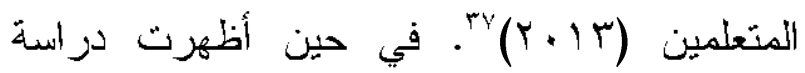

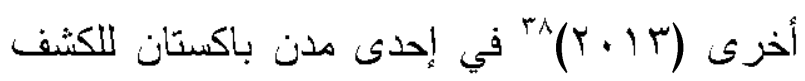


شهري وذلك بنسبة VV متوسطة مرتفعة تبلغ نسبتهن اب٪ ومن هن من أسر إما بذخل مرتفع أو منخفض تبلغ نسبتهن ^ـ٪

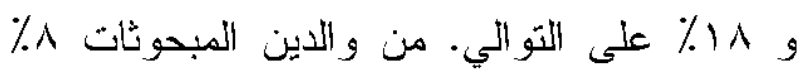
من الامهات و, ؟\% من الإباء إما اميين أو بدون

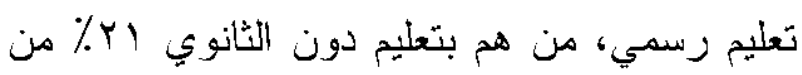
الامهات و r \% من الإباء، مب \% من الامهات بتعليم ثانوي و سء٪ من الإباء، في حين بلغت نسبة الامهات الحاصلات على شهادة جامعية بـ

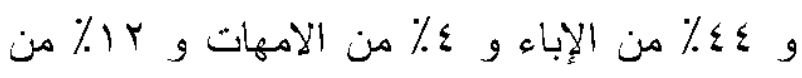
الآباء يحملن شهادة ماجستيز أو دكتور اه. أما عن الوضع الاجنماعي للأبوين: ما يقارب . 1\% من المبحوثات و الايهم منفصلين أو مطلقين، وما يقارب ء ٪ من الاباء مرتبطين بأكثر من زوجة. 0ب\% من الاباء يعملن في مهن حكومية و ه, ؟ في مهن عسكرية و ب ا في القطاع الخاص. أما الأمهات فغالبيتهن ربات منزل بنسبة تقارب ع ؟ و هذا يثو افق مع واقع المجتمع السعودي حيث لا تتجاوز

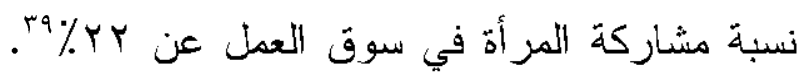
جميع المبحوثات من سكان مدينة جدة وما حولها باستثاء س مبحوثات من سكان مدينة مكة المكرمة، أما عن الحي السكني فقد بلغت نسبة المبحوثات اللاتي يقطن في أحياء شمال جدة . ب\%، هب\% في
๑. ما هو موقف الفنيات من تذخل الجهات الرسمية لحماية القتيات من العنف الأسري؟

منهجية اللار اسة:

اعتمدت اللاراسة على منهج المسح الاجثماعي وذلك بتوزيع استمارة تحتوي ثلاثة وثلاثون سؤالاً على . . . طالبة من طالبات السنة التحضيرية بجامعة الملك عبدالعزيز، تم استبعاد ب. . ب استمارة لعدم اكتمال إجابة جميع أسئلة الاستمارة وبلغ عدد الاستمار ات التي تم اعتمادها في الاراسة . . اسثمارة فقط.

ما يقارب من T/\% من المبحوثات هن في الفئة العمرية من (1) (- . ب)، يلي ذلك الفئة العمرية التي يبلغ عمرها من (Y-Y-Y)، النسبة الباقية هي إما لمبحوثات أعمار هن أقلى من 11 أعام أو أكثر من ك r عام. 19 من المبحوثات غيز متزوجات وذلك ليس بمسنغرب نظر اللاتفاع سن الزواج في المجنمع السعودي لما بعد الذراسة الجامعية أو سن ال ب Y عام، المبحوثات المخطوبات بلغت نسبتهن ^ مقط، مبحوثة واحدة مطلقة ومبحوثثان متزوجنان. أما عن السمات الايموجرافية لأسر المبحوثات فقد تفاوت مستوى الذخل الاسري الشهري، النسبة الأعلى من المبحوثات هن من الطبقة المتوسطة

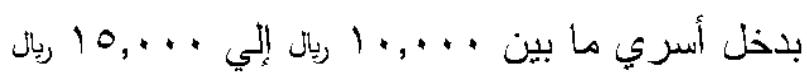


المبحوثات في أسر يبلغ عدد اطفالها سبعة وما

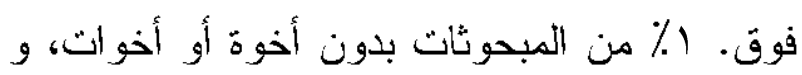

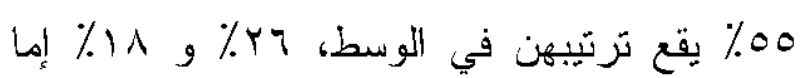

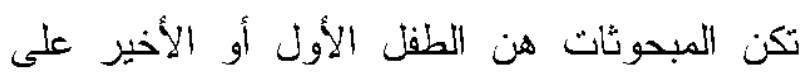

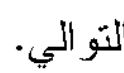

أحباء وسط جدة، ، ب\% في أحياء شرق جدة و 10 في أحياء جنوب جدة. النسبة الأعلى من المبحوثات ينتمين لأسر متوسطة جدة ابدة

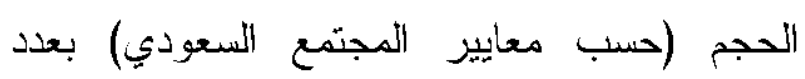

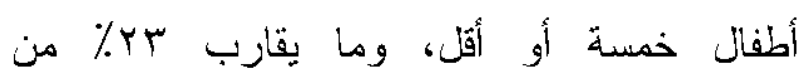
الجدول (1) رأي المبحوثات في الثئات الأكثر تعرضا للعنف الأسري

\begin{tabular}{|c|c|}
\hline النتسبة & الفئات \\
\hline$\% r r, v y$ & الأطفال بشكل عام \\
\hline$\% r_{q}, r_{0}$ & الزوجات \\
\hline$\% r v, i v$ & الفتيات \\
\hline$\%$ \%, 11 & الأطفال الإحاث \\
\hline$\%, \vee$ & الأطفال الذكور \\
\hline$\% \ldots$ & المجموع \\
\hline
\end{tabular}

المراحل باختلاف المجتمعات و الثقافات. يث ساهم الأطباء و الدعالجين النفسيين وتز ايد الاهنمام بحقوف الطفل والإعلام بما يعكسه من صور

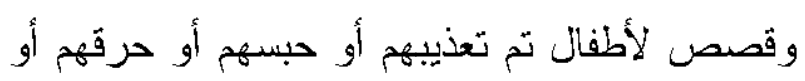

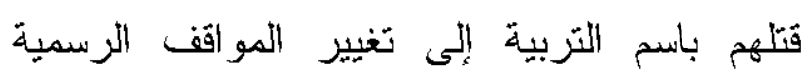
و الشعبية تجاه الحق المطلق للوالدين في الستخدام

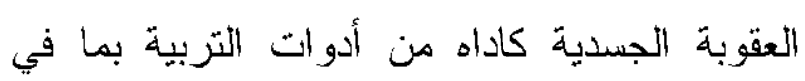
ذلك المملكة العربية السعودية من خلا نل نظام الحماية من الإيذاء" الأبي نم إقزاره في العام . r. Ir

هناك تقارب في نسب الجدول (1) حول الفئات

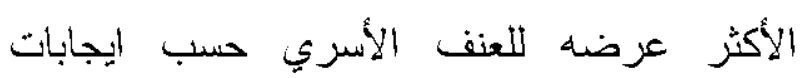

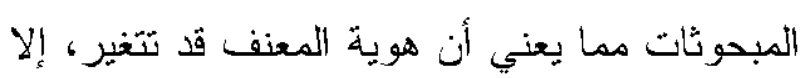
أن الضحايا ثابتين لا يتغيرو و هم الأطفال و النساء.
تعكس إجابات المبحوثات ما يؤكد اعتماد الأسرة

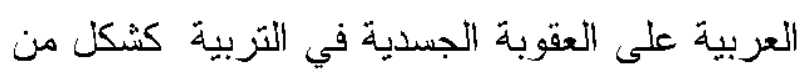
أشكال التأديب، حيث إن عنف البالغين ضد الأطفال

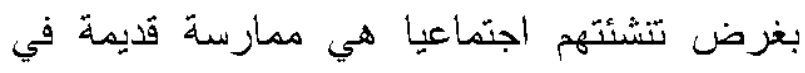
تاريخ البشرية، ففي كل المجنمعات هنالك امثلة كثيرة لأطفال تعرضوا للتعذيب، التجويع وأجبروا

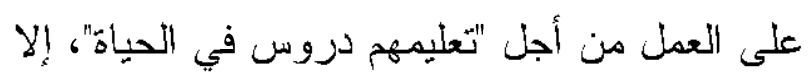

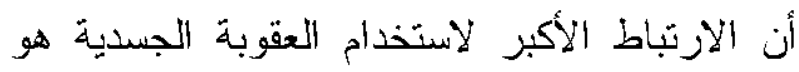

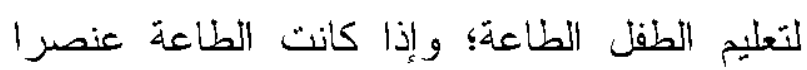
أساسيا في التتشئة الاجتماعية فلا شيء أكثر فعالية من العقاب الجسدي لتحقيق هذه الغاية كوسيلة

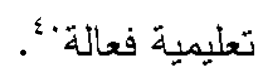
و العقوبة الجسدية كسلوك و أداه من أدوات التزبية

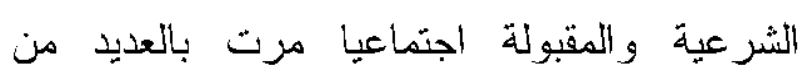


إلا ان تفوق نسبة من يعتقد من المبحوثات أن الأطفال الذين تم إيذاؤهم يليهم من هم في سن

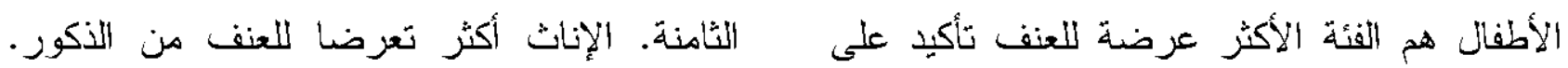

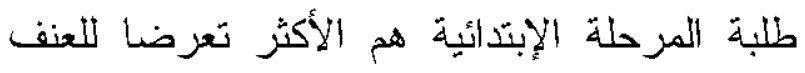

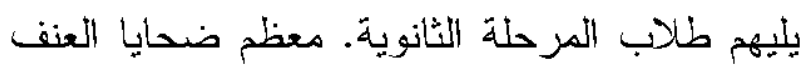
من سكان الأحياء الشعبية ثم الأحباء المتوسطة. يأتي العنف النفسي (اللفظي) و الجسدي كأكثر أنواع العنف ممارسة ثم الجنسي. الاباء أكثر ممارسة للعنف ضد أطفالهم تليهم الأمهات ثم الأخئ وأخير ا معظم ممارسي العنف من الاباء لديهم أكثر

من زوجة. هناك أيضا دراسة مركز الأمان الأسري عن

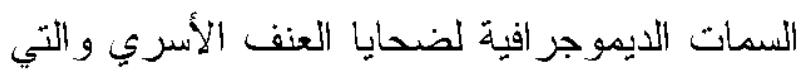
تم جمع بياناتها من سجلات ( Y T ) من مرضى

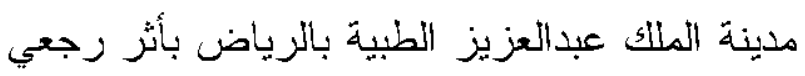

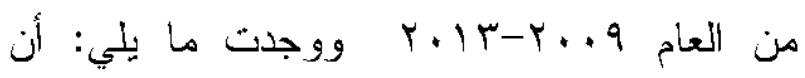
الاعتداء الجسدي اكثر أنو اع الاعنداء شيوعا وذلك ونك

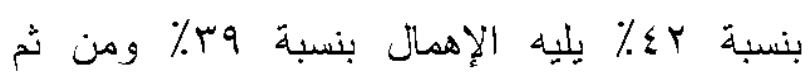

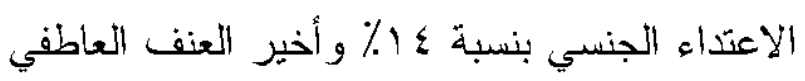

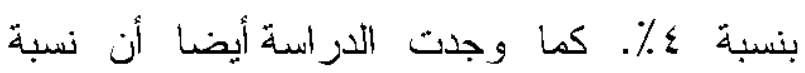

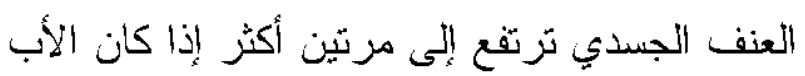

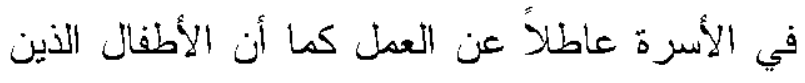

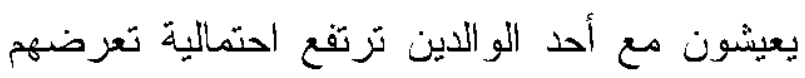

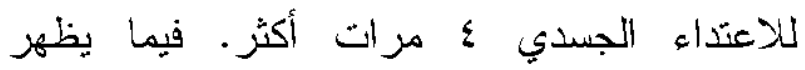
الإهمال بين الأطفال الذين يعيشون ضمن أسن أسر

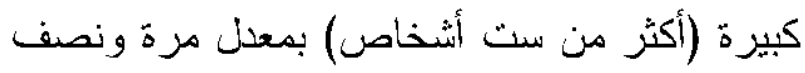
أكثر من الأطفال الذين يعيشون في أسرة أقل عددا. ما يطرحه الباحثون من أن العنف ضد الطفل أهم الهم

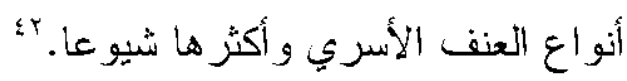

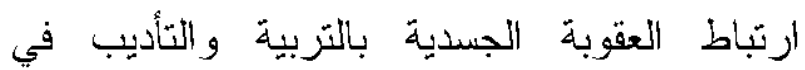

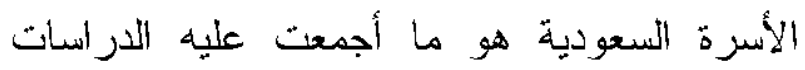

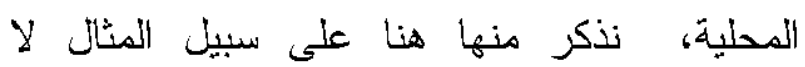

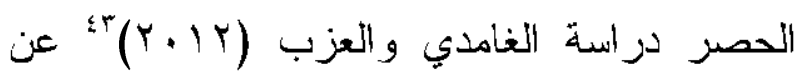
العو امل الاجتماعية و الاقتصادية المرتبطة بأنماط العنف الأسري ضد

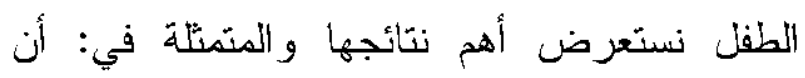
العنف الجسدي هو أكثر أنو اع العنف استخداما ضد وند الأبناء في الأسرة ، ثم يليه النفسي و الجنسي، أن أن النئ

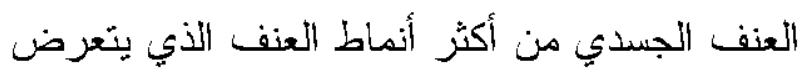
له الأبناء تكر ار في عينة الدراسة وبلغت نسبة من العن

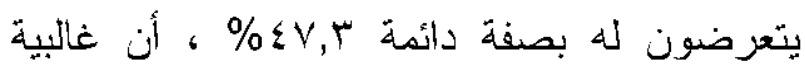
الآباء يمارسون العنف ضد الأطفال في الأسرة بغرض التزبية و التتأديب ثم يليهم من يستخدمونه

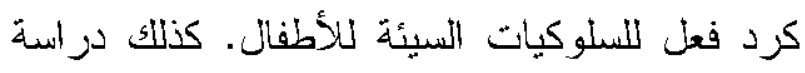

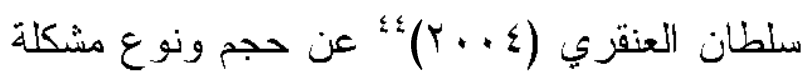
إيذاء الأطفال في المجنمع السعودي وخصائص النص هؤلاء الأطفال من حيث الجنس، العمر، المسنّوى التعليمي، المدينة ونوعية الحي الذي يقيم فيه لهيه الو الدين المعنفين، الحالة الصحية للأطفال و وأباء

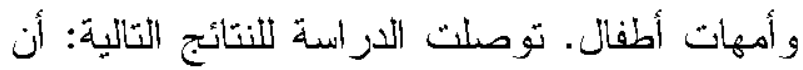

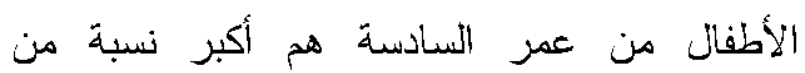




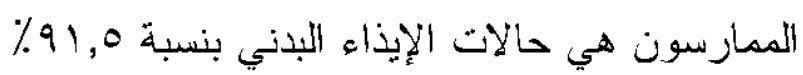

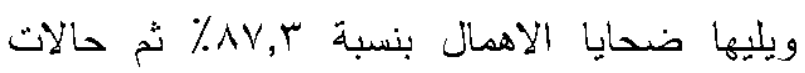

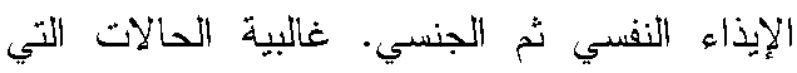
تعامل دعها الممارسون هي حالات وقع عليها لإناه الإيذاء من قبل أحد الو الدين سواء الأب أو الأم

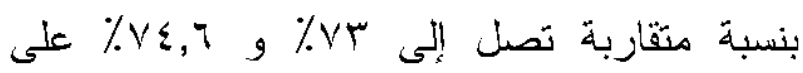
التو الي وتتزايد نسبة تعرض الأطفال للإيذاء كلما صغرت أعمار هم.

أما ما يخص الاعتداء الجنسي، فإن الأطفال الذكور أكثر عرضة من الإناث بمقدار الضعف. ه؛ كذلك الضكاء

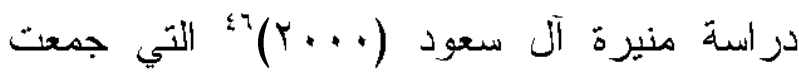
بياناتها من حالات الإيذاء في المستشفيات السعودية

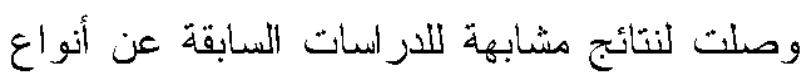
الإيذاء التي يتعرض لـ هؤلاء الأطفال واسبابه

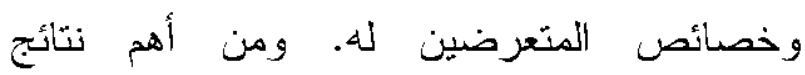
الدراسة: أن أكثر أنواع الإيذاء التئين تعامل معها الجدول (r) حجم ظاهرة العنف في المجتمع السعودي

\begin{tabular}{|c|c|}
\hline إنسبة & 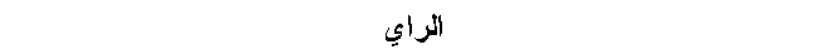 \\
\hline$\% \varsigma \varepsilon, Y$ & موجودة ولكن ما يعرف عنها أقل بكثير معا هي عنيه عثى أُرض التواقع \\
\hline$\%$ \%, 1 & موجودة بالثكل الأذي هي عليه في المجتمعات الأخرى \\
\hline$\% 11, v$ & موجودة ولكن هناك مبالغة في طرحها \\
\hline$\% \ldots$ & انمجموع \\
\hline
\end{tabular}

السعودي لأرقام دقيقة تشخص و اقع العنف الأسري بشكل عام، والعنف ضد الأطفال بشكل خاص. ولجمعية حقوق الإنسان الوطنية، اجتهادات في هذا

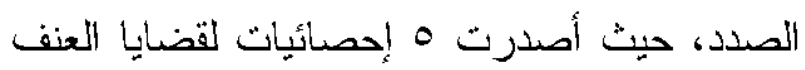

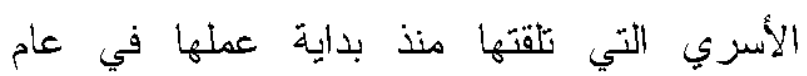

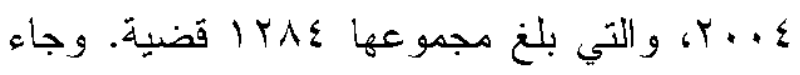

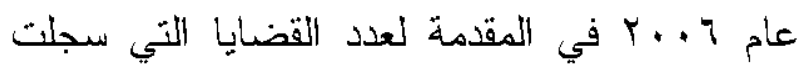

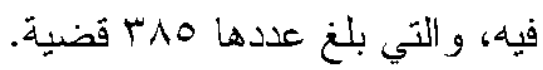

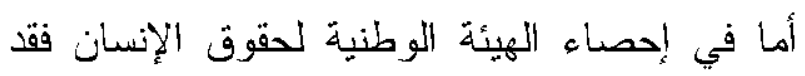

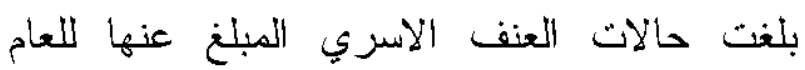

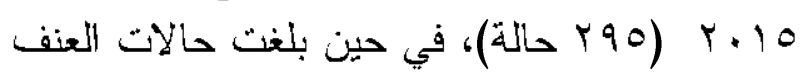

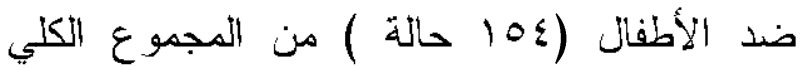

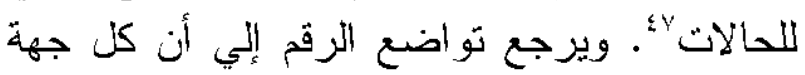
تتعامل مع بلاغات أو ضحايا العنف تصدر الري
في الجدول (Y)، نزى غالبية المبحوثات (ع ؟ ٪) أن العنف الأسري كظاهرة موجودة بالمجتمع السعودي

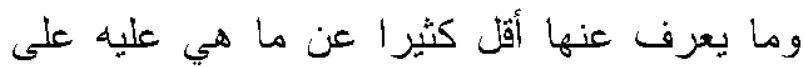

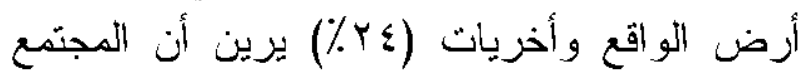

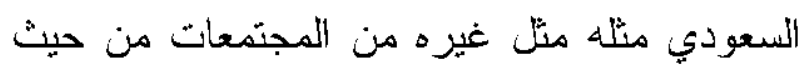

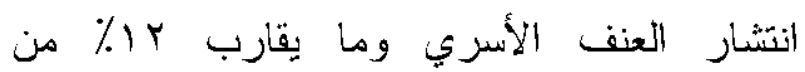

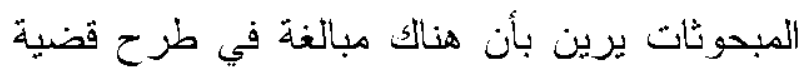
العنف الأسري من قبل الإعلام و الار اسات العلمية.

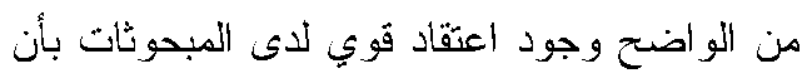

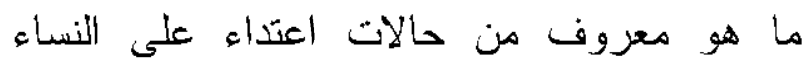

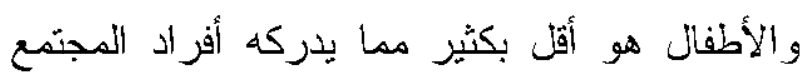

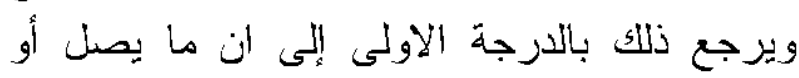

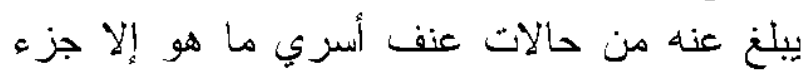

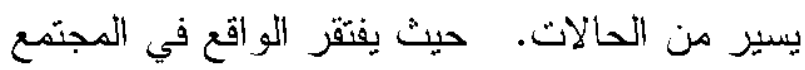


وعن العنف ضد الفتيات اختلفت المبحوثات في

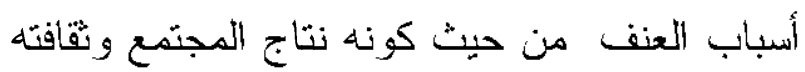

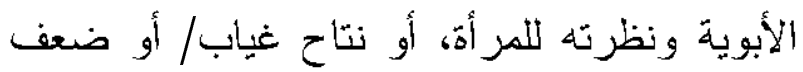

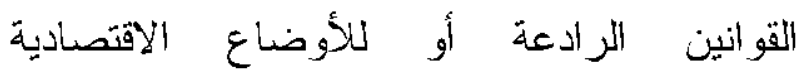

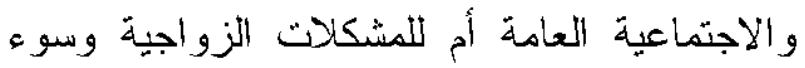

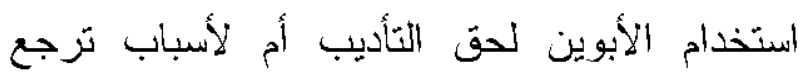

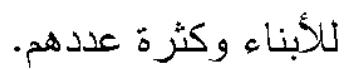

احصاءها بالحالات التي تصلها فقط وبالتالي هذا

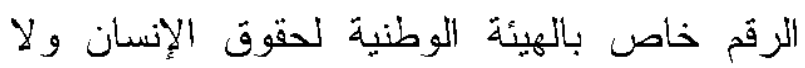

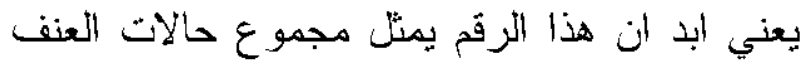

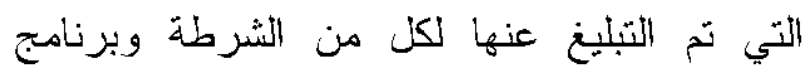
الأمان الأسري و إدارة الحماية بوزارة العمل الإنة

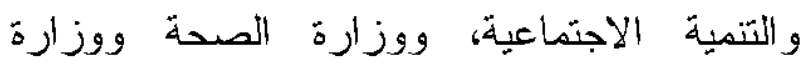
التعليم ووزارة العدل مجتمعه.

جدول (r) السبب الرئيسي لظاهرة العنف ضد الفتيات في المجتمع العسودي

\begin{tabular}{|c|c|}
\hline النسبة & السبب الزئيسى للعنف ضد النقتيات \\
\hline$\% \wedge, \circ \mathrm{V}$ & المفهوم الخاطىى للقو امة \\
\hline$\% 14, .9$ & ثقافة المجتمع القائمة على التقليل من شأن الانثى \\
\hline$\% 10,00$ & عدم وجود قو انين رادعه ضد المعنف \\
\hline$\% 10$ & كثرة الضغوطات التى يتعرض لها المعنف \\
\hline$\%$ \% r, rq & عدم نو افق الأبوين \\
\hline$\% r, \leqslant r$ & المجتمع الذّي يعطى الأبوين الحق فى الثأديب بأي شكل \\
\hline$\%$ \%,qv & كثرة عدد الأبناء - كئاء \\
\hline$\% \varepsilon$ & عدم كفاية الدخل \\
\hline$\%$ & 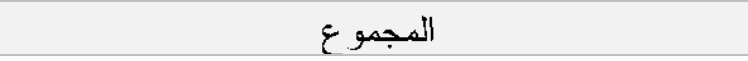 \\
\hline
\end{tabular}

النهائي الذب يسيطر على جميع الممنكات وجميع الأفراد المقيمين في الأسرة. وبالتالي تتطلب التقافة

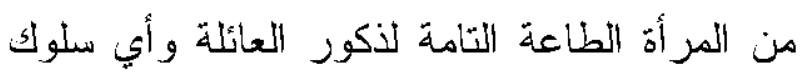
ينظر له على ان فيه خروج عن هذا الإطار يتم مقابلته بالعنف. لـفر وبسؤال المبحوثات عن المراحل العمرية التي

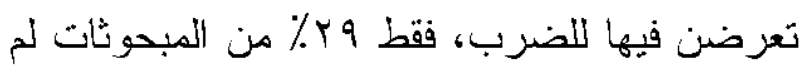
يتعرضن للضرب خلا مر احل نموهم في حين ما يقارب 11\% خلال سنوات الطفولة المبكرة (من

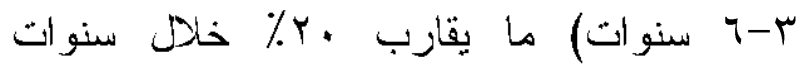

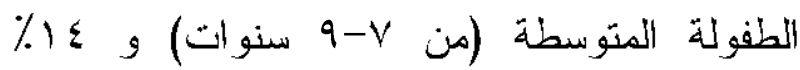

المجتمع السعودي لديه مو اقف محافظة تجاه أدوار الجنسين، وسلوك الرجل و المرأة يخضع بشكل لائل

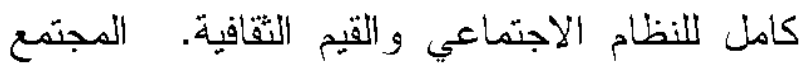
السعودي كذلك مجتمع أبوي، لرب الأسرة الامتياز

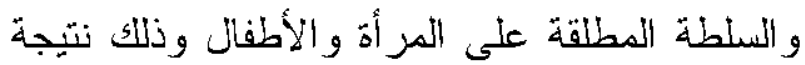

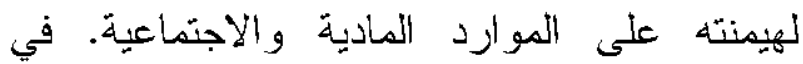
التقافة ينظر للرجل على انه رمز للقوة والاستقلا لهل و العدوانية في حين ينظر للنساء على أنهن ضعيفات، خاضعات و عاطفيات. أما توزيع السلطة فهو هرمي، الأكور في الاسرة منفوقين و النساء و الأطفال هم المرؤوسين. كما يعتبر الزوه الحاكم 
و السويد. توصلت إلى الثتالي: في سبعة من الدول

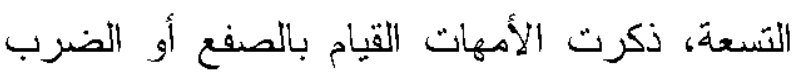

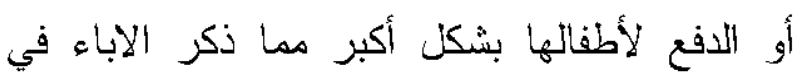

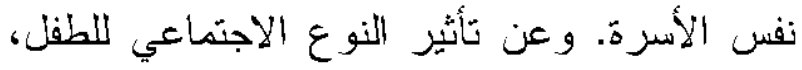

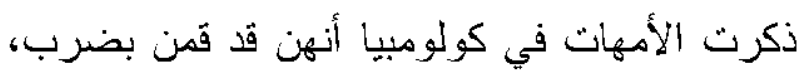

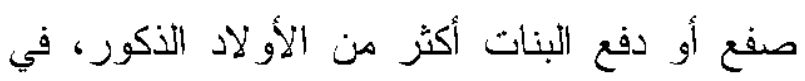

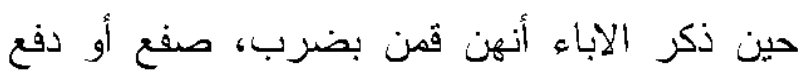
الأبناء الأكور أكثر من الاناث. وفي بقية الأدول

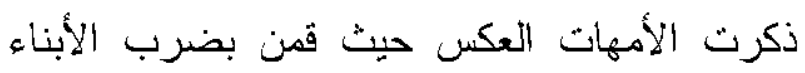
الذكور أكثر من البنات وكذلك الحال بالنسبة للاباء. كذلك وجدت الار اسة نتائج مهمة على مسنوى استفتاء الأطفال في نفس الدول التسع حيث أفاد الأطفال الكينين والأردنيون أن أمهاتهم يضربن،

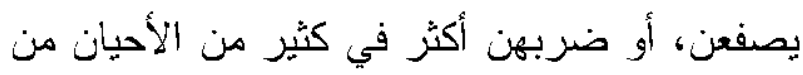

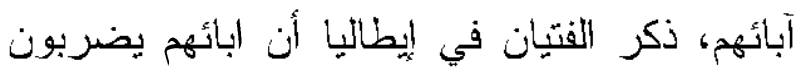

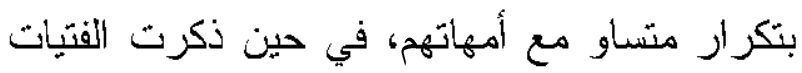

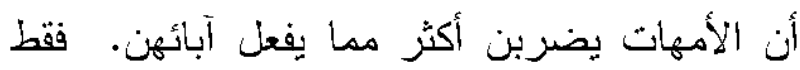
في كولومبيا و الفلبين لم يكن هنالك تأثير رئيسي الثين

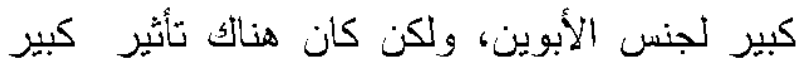

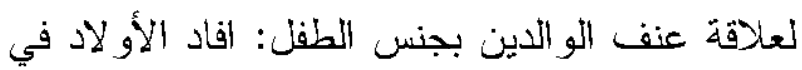
كولومبيا و الفلبين أن آبائه يقومون بضربهر أكثر الكثر

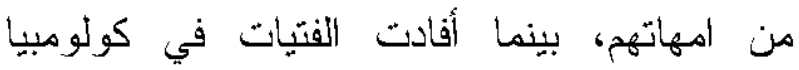
و القلبين بأن الأمهات يضربن أكثر مها يفعل الآباء، وتتساوى نتائج بقية الدول من حيث أن الاولاد يسجلون تعرضهم للضرب بشكل أكبر مما تسجله
خلال سنوات الطفولة المتأخرة (من • 1-Y ( سنة). أما من تعرضت منهن للضرب خلا لمل المر اهقة فقد

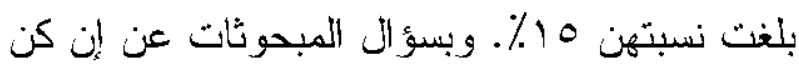

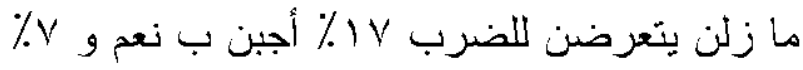
أجبن ب أحيانا. ويشكل الأب المعنف الأساسي لمني

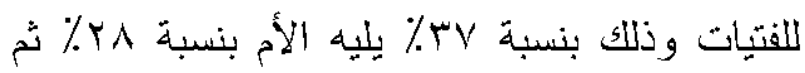

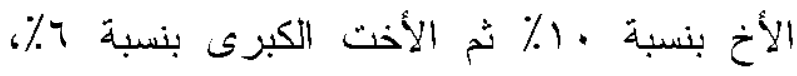

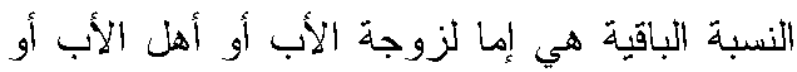
لأكثر من معنف في العائلة مثل الأب والألم الأم الابه

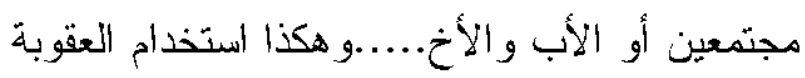
الجسدية في التربية هو قاسم مشترك بين دراسات الهات

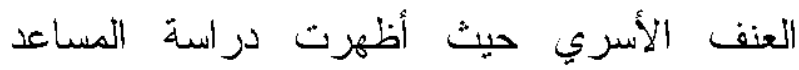

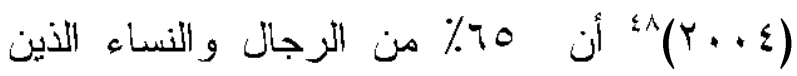

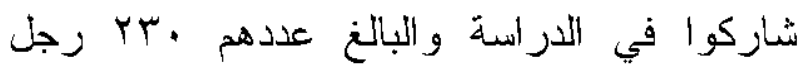

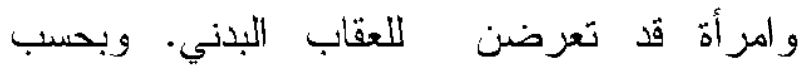
الدر اسة فإن استخدام العقاب البدني أكثر شيوعًا لتعليم

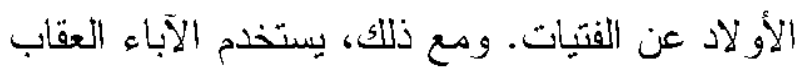
البدني مع الأولاد أكثر من الأمهات، و والأمهات

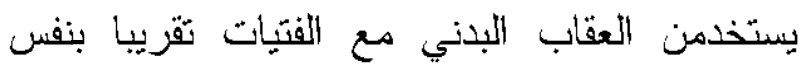

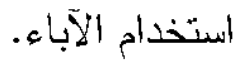
وفي الدراسة التي قامت بها جينفر لانسفورد

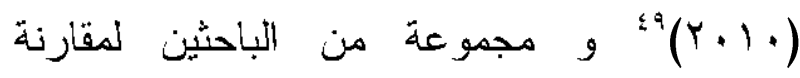
استخدام العقوبة الجسدية في التزبية وارتباط ذلك الته بالنوع الاجتماعي للأبوين و الطفل، و التي غطت

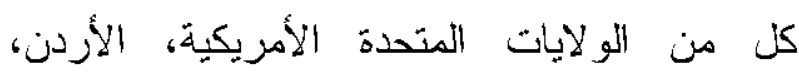
كولومبيا، الصين، ايطاليا، تايلاند، كينبا، الفلبين 
ما يمكن قوله هنا أن الأمهات لا يختلفن عن الاباء و هذا ما بجعلها تتعرض لعنف لا يقتصر على الأب

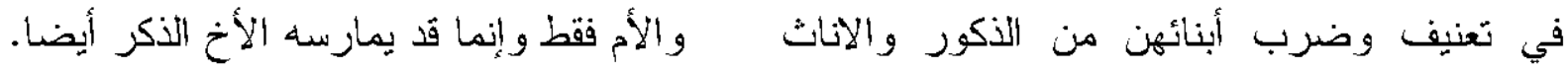
خلا عمليه التزبية، بل يمكن القول أن الأبناء غالبا ما تستخدم "التقافة" لتبرير العنف ضد النساء

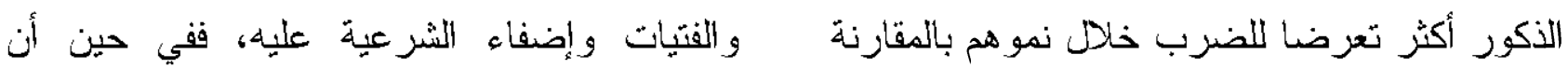
مع الفنيات. ولكن باشتداد عود الصبي قد يتوقف

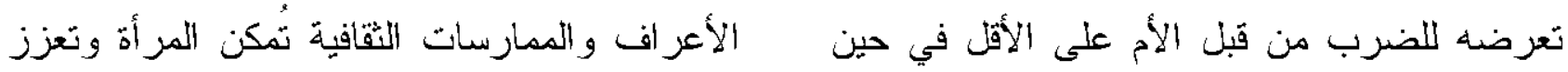

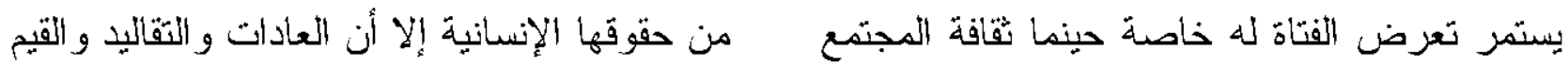

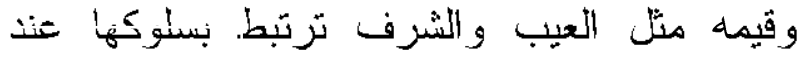

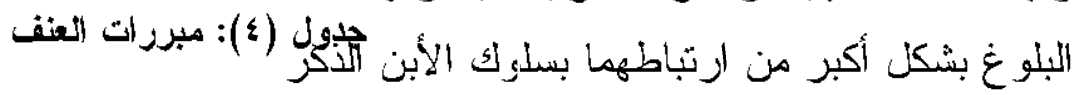

\begin{tabular}{|c|c|}
\hline الأنسبة & متى يكون ألعنف ضد الفتاة مبررا \\
\hline$\% r r, 09$ & عندما تخرج في سنوكها عن تقالثيد الأسرة والمجتمع (مثل كثف وجهها، الثتأخر في التعودة للمنزل، إنثاء علاقة مع الجنس الآخر) \\
\hline$\% \cdot r, 74$ & لا يوجد ما يبرر العنف \\
\hline$\% 14, \wedge 0$ & عندما تختلق المشاكل داخل الأسرة \\
\hline$\% 1 \cdot, v \vee$ & عندما تستفز المعنف \\
\hline$\% y, \circ \varepsilon$ & عنما تعصي إلثتاة أو أمر إلمعنف \\
\hline$\%, Y, Y$ & عندما لا تشارك في أعمال المنزل \\
\hline$\% 1+$ & المجموع \\
\hline
\end{tabular}

استخدام القيم اللقافية كمبرر للعنف ضد المرأة يخلق إطار متذاخل ومعقد كما تزاه شاينا غريف

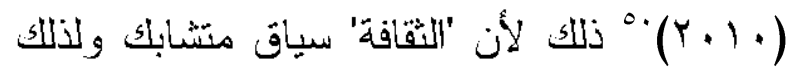
فهو ليس كيانا ثابتا أو غير قابل للتغيير ولكنه سياق محدد بناء على متغيرات مثل المساحة

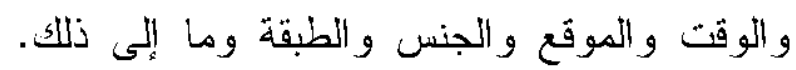

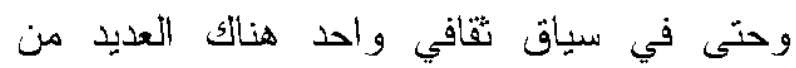

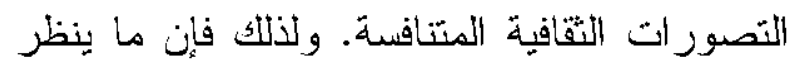
إليه غالبا على أنه ثقافة فردية هو في الو اقع الثقافة
الأعر اف و الممارسات الثقافية تُككن المر أهُونعزز من حقوقها الإنسانية إلا أن العادات و الأقاليد و القيم

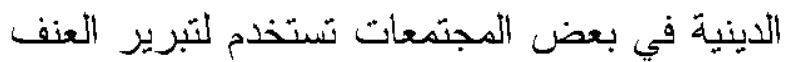

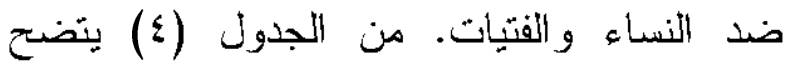

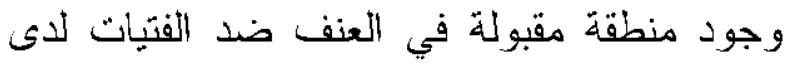

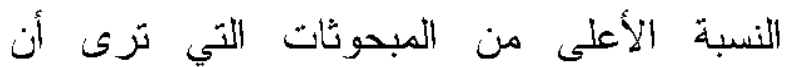

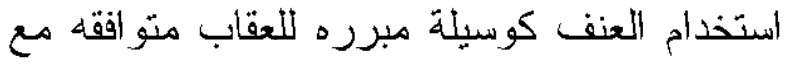
حجم الضرر الذي قامت به الفتاة: وذللك هو هو الخروج عن القيم التقافية للأسرة و المجنمع. إلا أن 
(حو التي • مليون) قالو ا إنهم وقعو ا ضحايا لشكل من أشكال العنف الجسدي منذ سن الخامسة عشرة.

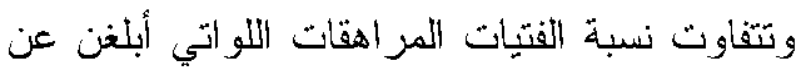

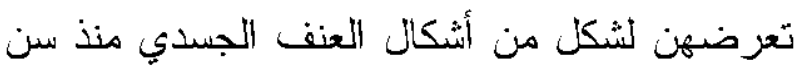

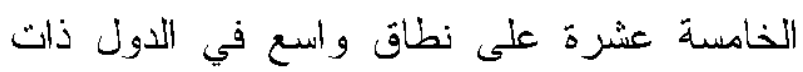

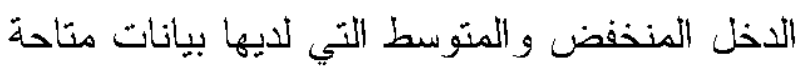

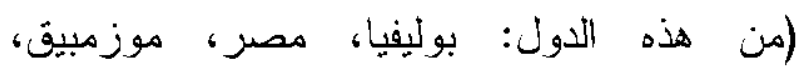

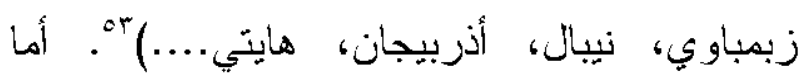
عندما يتعلق الأمر بمرتكبي العنف الجسدي ضدال

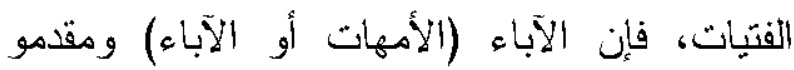
الز عاية الآخرون (زوجات أو أزواج أمهات) أكثر الأباه

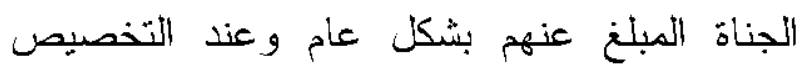
تكون الأههات وزوجات الاباء الأكثر تعنيفا للفتيات.

الثقافة بقيمها ومبادئها و أشكالها وصورها ليست

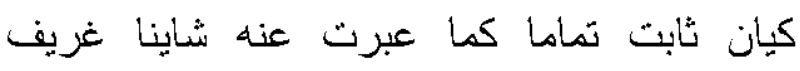

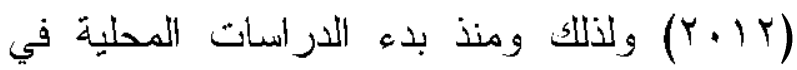
رصد اتجاهات المجنمع السعودي نحو العنف، لأف

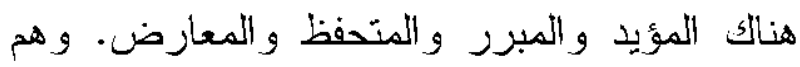

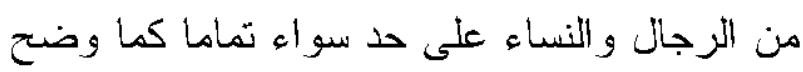

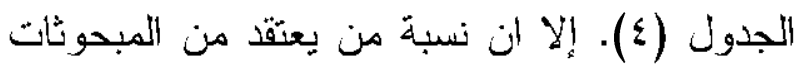

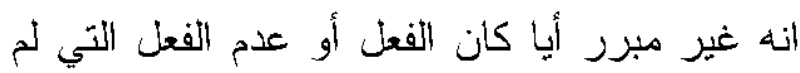

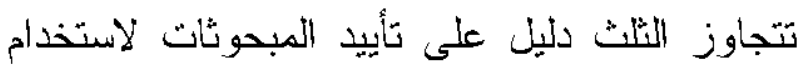
العقوبة الجسدية للتأديب حتى عندما تتجاوز الفتاة سن التأديب.
المهيمنة وخصوصا عندما يتعلق الأمر بقضية

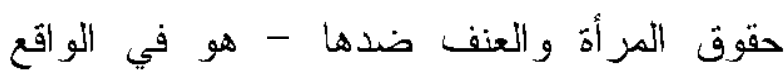

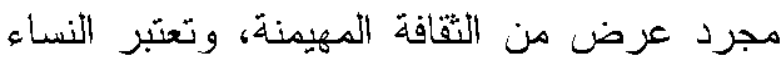
رمزا لتلك "الثقافة" وحاملة لها ويصبح جسدها ساحة للنسبية الأقافية. من الجدول يتضح خضوع المبحوثات للقيم الثقافية الأبوية التي تحبذ قاعدة التفوق الذكوري وتمنح

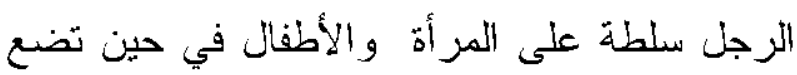
المرأة في مركز ثانوي، كما بئضح من الجدول قبول غالبية المبحوثات استخدام العنف لمعقابة الفتاة التي تخرج عن هذه القيم. فالفتيات مثنا يعاقبن أكثر

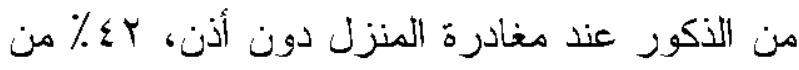

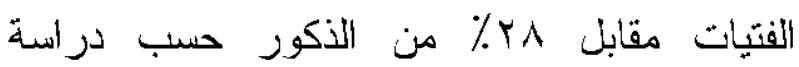

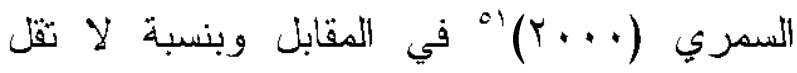
كثير اعن السابقة هناكك مبحوثات يققن ضد وجود مبررات لاستخدام العنف. و السؤال هنا هل هنآك

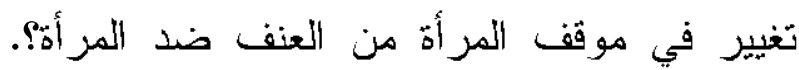
بحسب تقزير اليونسيف (2014) به استخدام العقوبة الجسدية في التزبية هي ممارسة يخضع لها معظم الفيل الأطفال في العديد من الأدول حول العالم داخل فئل

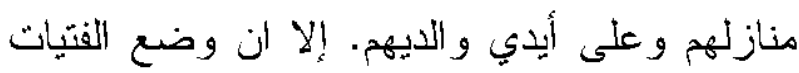
يختلف فهن قد ينعرضن للعقاب الجسدي من قَبل الو الاين حتى أو اخر فتزة المر اهقة أو حتى الثباب.

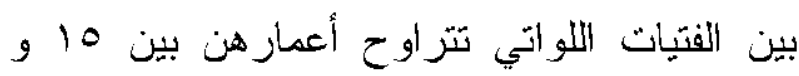
19

جدول (0) أكثر أنواع و أشكال العنف ضد الفتيات انتشارا

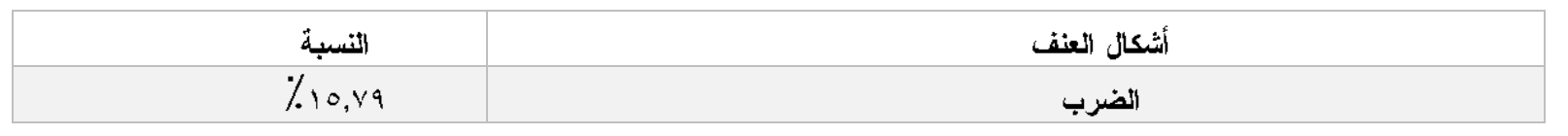




\begin{tabular}{|c|c|}
\hline$\% \wedge r, \wedge 7$ & المنع أو التهلهيد بالمنع من التعليم أو العمل \\
\hline$\% 9, v r$ & التحرش الجنسي من قبل المحارم \\
\hline$\% ৭, \leqslant \wedge$ & عدم أخذا الزأي في الزواج \\
\hline$\% 9, \cdot 9$ & الثشتم و التحقير \\
\hline$\% 9, \cdot 7$ & الاستيلاء على راتجها \\
\hline$\% \wedge, \uparrow \wedge$ & العضل (المنع من الززواج) \\
\hline$\% \wedge, \infty$ & لالحبس أو المنع من الخروج \\
\hline$\% \wedge, 01$ & التززويج المبكر \\
\hline$\% \wedge$, ro $_{0}$ & التحرمان من الميراث \\
\hline$\% 1 \ldots$ & المجموع \\
\hline
\end{tabular}

تتعدد أشكال وصور العنف ضد الفتبات بناء على تتفق المبحوثات في الجدول (0) على اشكال

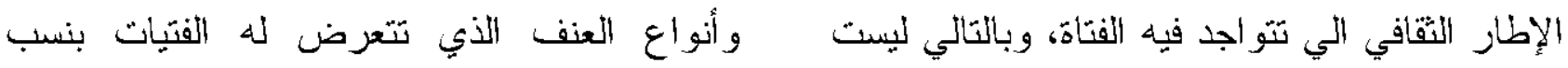
كل أشكال العنف الذي عبرت عنها المبحوثات منقاربة وهي متمثلة في: تفضيل الذكور عليها تتعرض له الفتبات في المجتمعات الأخرى حتى لو داخل الأسرة، الحرمان أو التهديد بالحرمان من

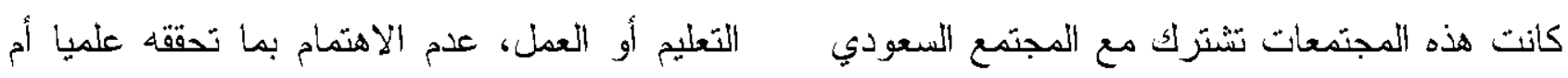
في اللغة و الدين و القيم الثقافية الاساسية. أشكال مهنيا، عدم الاهنمام بتوفير احتباجاتها، الضرب،

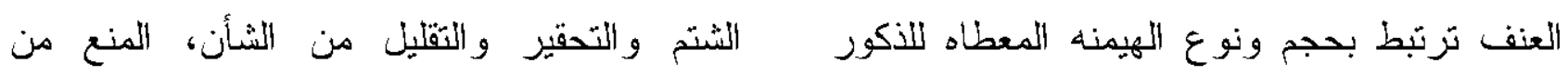
في المجتمع الأبوي ولذلك يمكن القول بأن الفتيات الخروج، المنع من الزواج للاستيلاء على راتبها او في المجتمع السعودي يتعرضون لإشكال من العنف مير اثها، الزواج المبكر، الإرغام على الزواج من قد لا تتعرض لها أو تعلم بوجودها الفتيات في شخص لا تزيده،. جميع هذه الممارسات تمثل

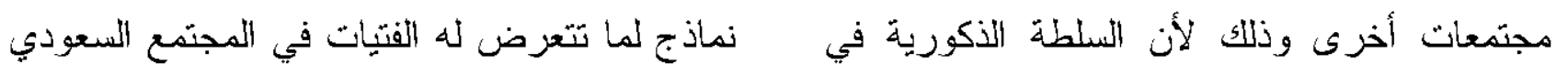
المجتمع السعودي هي في صورتها الأشد والأكثز وجميعها صور و أشكال للعنف ضد الفتيات.

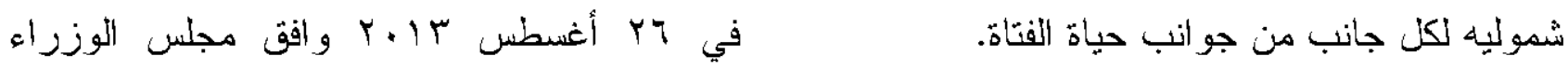
السعودي على قانون الحماية من الإيذاء حيث لم

جدول (آ) تدخل الجهات الرسمية

\begin{tabular}{|c|c|}
\hline النسبة & هل تؤيدي تلخل الجهات الزسمية لحماية الفتيات ضحايا العفف الأسري \\
\hline$\%$. & نعم \\
\hline$\% r 4,4$ & في الحالات الثديدة فقط \\
\hline
\end{tabular}




$$
\begin{aligned}
& \% r, \varepsilon \\
& \%, \ldots
\end{aligned}
$$

ע

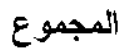

الجهة المعنية أن الإيذاء يرقى إلى مستوى جنائي

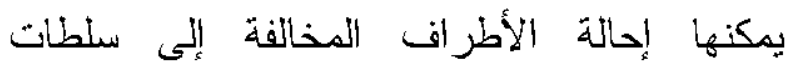
القضاء الجنائي للتوقيف و الملاحقة القضائية. يفرض القانون عقوبة للإيذاء الأسري تتراوح بين

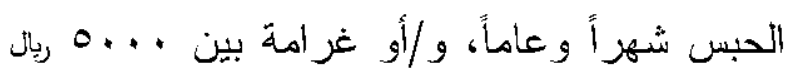

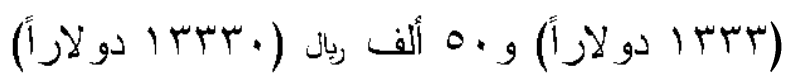
ما لم تتص أحكام الشريعة على عقوبة أغلظة ويمكن للقضاة مضاعفة العقوبات المقررة في حال تكرار المخالفين لأعمال الإيذاء.

حقيقة لا يعرف مدى الاختلاف الذي أحدثه نظام حماية الطفل من الإيذاء ومدى حرص الجهات المعنية على القيام بما عليها من مسئوليات منعلقة

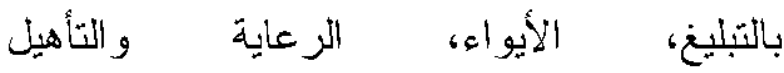
و التوعية..........كن من المؤكد أن نظام الحماية النهاهية يختلف بعض الشيء عندما بيتعلق الأمر بعنف موجه ضد فتاه أو زوجة من حيث أن كلاهما قادر لأن بعري على الوصول إلى الجهات الأمنية للتبليغ وطلب الحماية. كما من الملاحظ على النظام أُيضا انه لم ير اعى اختلاف العنف باختلاف النوع الاجنماعي

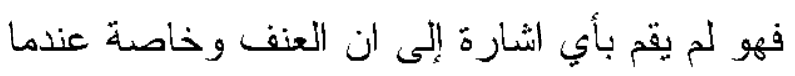
يتعلق الأمر بالفتاة قد يأخذ بأنواعه الجسدي،

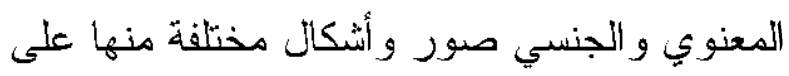
سبيل المثال لا الحصر الختان، المنع من التعليم
تكن لاى سلطات القضاء الجنائي سابقا أدلة إرشادية قانونية مكتوبة عن معاملة الأذى الأسري كسلوك إجر امي. وفي غياب قانون العقوبات يعتمد القضاة بشكل حصري على تفسير اتهم الشخصية للشريعة في تحديد ما إذا كانت أعمال بعينها تعد لتهن

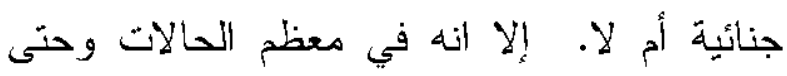
اليوم ماز ال المعنف لا يدفع ثن إساعتّه واعتداءه على ابناءه أو زوجته بشكل رادع. من أهم ملامح

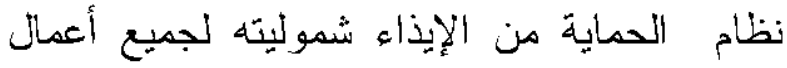
العنف والاستغلال التي يمكن أن يتعرض لهاه لهاه الطفل. وبذلك يصبح للجهات الحكومية سلطة التخخل في حالات وفوع الإيذاء الأسري، بما في ذلك لضمان تلقي الضحايا الرعاية و الخدمات الصحية الملائمة، واتخاذ خطوات لمنع نكرر الإيذاء، وتوفير خدمات مشورة اجتماعية و أسرية، و الاستكاء، و إلزام الأطر اف التي ارتكبت الإيذاء بتوقيع إقرارات، و إجبار المخالفين على الخضوع

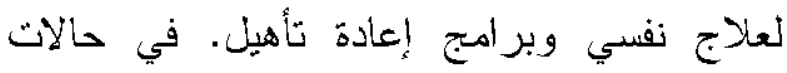
البلاغ عن خطورة الحالة أو أنها تشكل تهديداً لحياة من نعرض للإِيذاء أو سلامته أو صحته تقوم الجهة المعنية باتخاذ إجراءات إضافية مثل إحالة القضية إلى سلطة إدارية أو الأجهزة الأمنية،

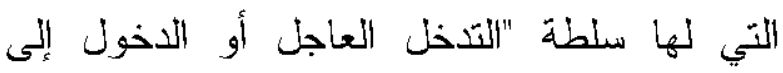

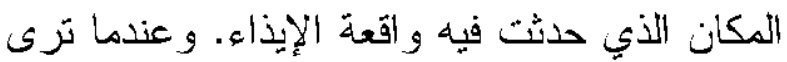


ذلك من ممارسات وفرص. و البعض الآخر لحين حصولها على استقلالها الاقتصادي.

مع انتقال الأطفال من مرحلة الطفولة المبكرة إلى الى المقال المراهقة، يمثل العنف السبب الأكبر للتوفيات. حيث ترتفع نسبة الوفيات الناجمة عن العنف بين الفتيات (من جميع الأسباب) من ع , • في المائة في

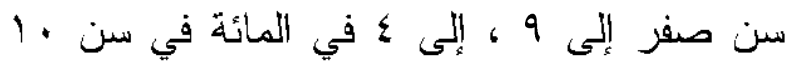

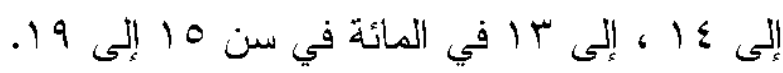

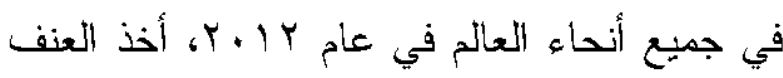

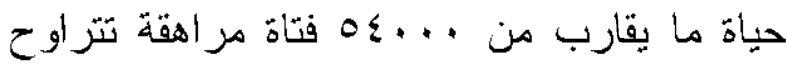

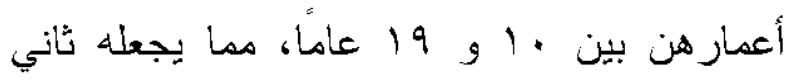
سبب رئيسي للوفاة بين هذه المجمو عة السكانية ،

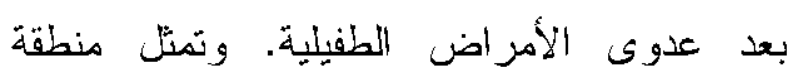

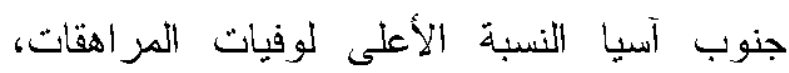

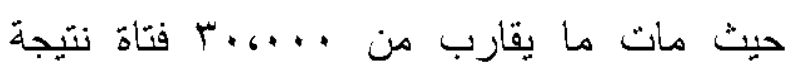

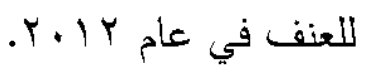

بتأثز العنف ضد الطفل بمجموعة واسعة من العوامل التي يناقشها تثريز الأمم المتحدة

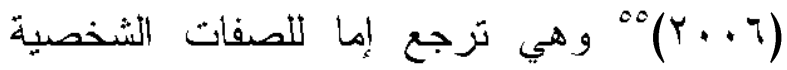
للضحايا و المعنفين أو إلى بيئته الثقافية و الفعلية. ويعد الخوف كما برد في الدراسة أحد أسباب بقاء العنف الموجه ضد الفتيات خفيا: إذ تخشى الكثير من الفتيات الإبلاغ عن حالات العنف الموجه ضدهن، وفي كثير من الحالات يبقى الو الدين
والززواج المبكر. من هنا يمكن القول أن نظام

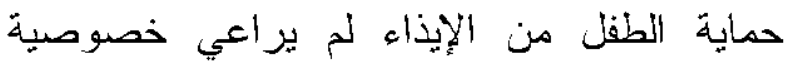
المجتمع السعودي في تعامله مع انواع الإيذاء التي لئي

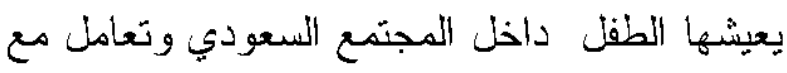

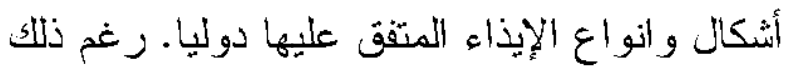
وكما يظهر الجدول (7) تؤيد المبحوثات تشخل الجهات الرسمية لحماية ضحايا العنف من الفتبات سواء كان في ممارسة العنف بالمطلق أو في مأي الحالات الشنديدة منه فقط.

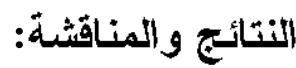

كل · ا دقائق، في مكان ما في العالم تموت فتاة مراهقة نتيجة للعنف بناءً على تقزير اليونسيف

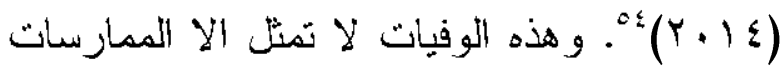
الاكثر تطرفا والاعتداءات التي لا رجعة فيها ضمن سلسلة طويلة من العنف تواجهه الفتيات المر اهقات على أساس يومي، وعلى أيدي الناس

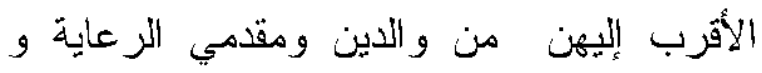

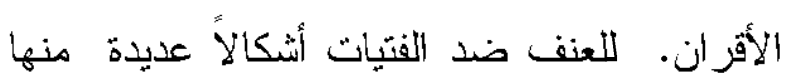
الجسدي و الجنسي و العاطفي، وتختلف خطورة ما قد نو اجهه الفتاة بحسب المساحة المكانية و الثقافية والاقتصادية المحيطة، فجنس الأثثى يأتي بنقاط ضعف فريدة من نوعها، البعض منها بعو اقب قد تذوم مدى الحياة منل التمييز بين الجنسين وما يتبع 
انتشار وخصائص عنف الزواج وعوامل خطر

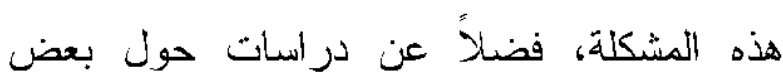

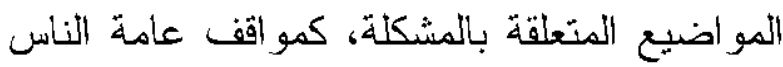

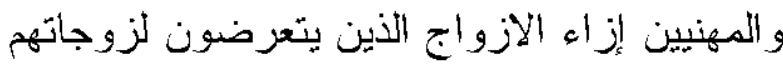

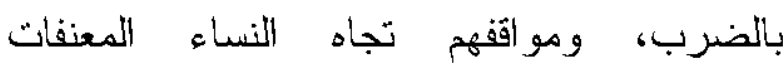
و المعتدى عليهن، بالإضافة إلى التدخلات

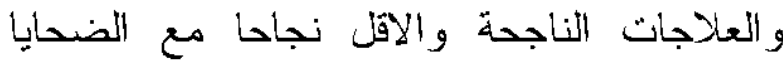

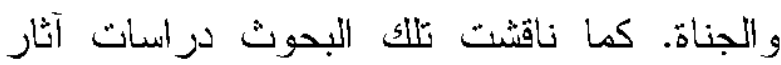
العنف ضد المر أة على صحتها النفسية، وسلوكيات و استز اتيجيات النساء في البحث عن المساعدة بهذف مواجهة العنف، وحالة الاطفال الذين

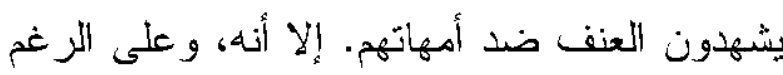

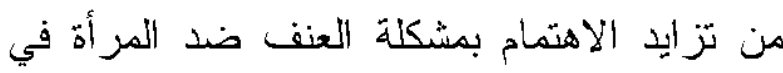
العالم العربي على مدى العقدين الماضيين، فإنه لايزال هناك نقص في الابحاث التي تجرى حول

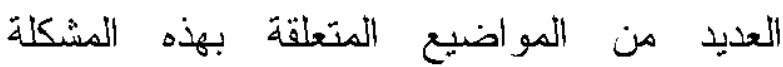

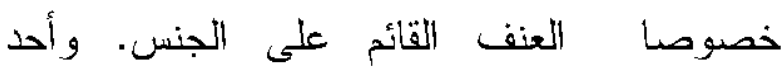
الجو انب الأساسية للعنف القائم على نوع الجنس

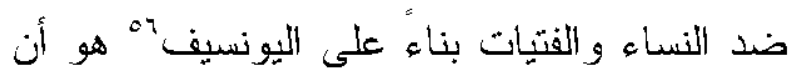
العنف بيتخدم في الثقافات في جميع أنحاء العالم باعنباره وسيلة لإبقاء واستمرار مركز الإناث

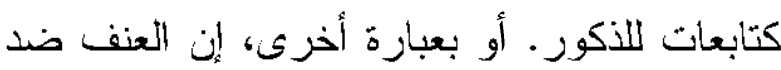
النساء و الفتيات يستخدم كتعبيراً عن هيمنة الأكور

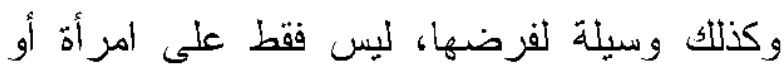
فتّاة بعينها، ولكن على الإناث كجماعة بشرية

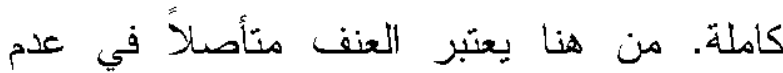

الذين ينبغي أن يحمين فتياتهم، صامتين إذا ارتكب العنف أحد من أفراد الأسرة. ويتعلق الخوف على لئ نحو وثيق بوصمة العار التي كثير| ما تلحق بالإبلاغ عن العنف لاسيما في المجتمعات التي يأتي فيها "شرف" الأسرة قبل سلامه الأبناء ورفاهيتهم.

إن قبول العنف على مستوى المجتمع أيضا عاملا مهما في عدم وجود معلومات دقيقة عن حجم وانتشار العنف ضد الفتيات. فقد تقبل الفتيات ومرنكبون العنف على السو اء بالعنف البدني و الجنسي و النفسي على أنه حتمي و عادي، كما ينظر إلى التأديب عبر المعاقبة البدنية و المهينة و التزرهبب والتحرش الجنسي على أنها وسائل عادية، خاصة عندما لا ينتج عن أي منها ضرر بدني "و اضح" أو دائم، ويعكس ذلك عدم وجود حد قانوني و اضح للعقوبة البدنية. إن العنف الأسري مشكلة عالمية ذات أبعاد هائلة.

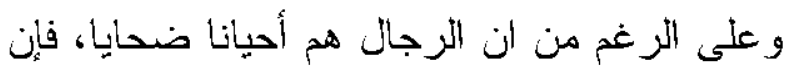

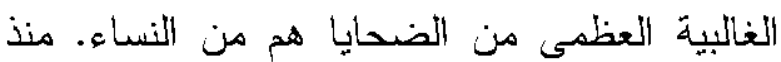
أوائل السبعينيات من القرن الماضي، أجريت هن منيك بحوث مستفيضة في كثير من المجتمعات في جميع أرجاء العالم حول مختلف القضايا المنعلقة بالعنف ضد المرأة من جانب زوجها وشركائها

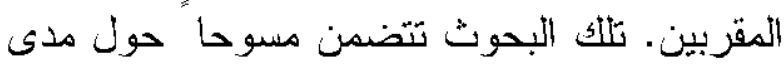


العنف الجسدي، النفسي و الجنسي ضد الفتاة كما له أيضا أن يحرمها من التعليم أو العمل أو يدفع بها للزواج مبكرا أو برجل لا تزغب فيه. الأم كذلك قد تمارس العنف الجسدي أو النفسي ضد بناتها، إلا انها ولكونها أنثى في مجتمع ذكوري فهي لا تملك أن تمارس الكثير من اشكال العنف التي هي حكراً على الأكور ولذلك الأخ وخصوصا في حالة غياب الأب يمارس ويتمنع بصلاحيات الأب لكون النظام يمنحه سلطه الولي على أمه و أخو اته الإناث الأصغر و الأكبر سناً منه.

اتفقت المبحوثات على وجود التعنف الأسري بالمجنمع السعودي وبصورة قد نكون أكبر بكثير مدا هو معروف عنها، كما اتفقت المبحوثات على بلى لئي أن الأطفال بأختلاف نوعهم الاجتماعي هم الفئات الأكثر عرضة للعنف يليهم الزوجات ثم الفتيات بrV,IV , ب Y Y,YO و \% على التو الي. و وانطلاقا من موضوع اللدراسة ونقطة تزكيز ها تثعرض الفتيات أشكال من العنف هول

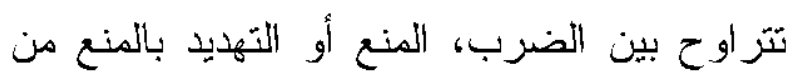
التعليم أو العمل، التحرش الجنسي، عدم أخذ الرأي بلي

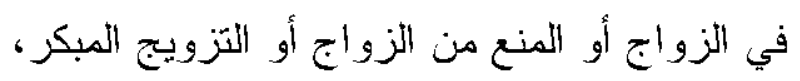

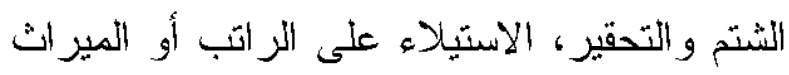

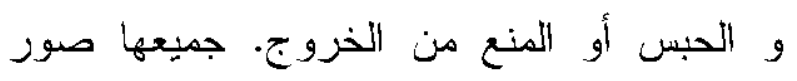
و اشكال للعنف قد لا تعزف معظمها أو بعض منها نساء بمجتمعات أخرى أو تقدر حجم الأذى الناتج عنها وصعوبة التعايش أو التأقلم معها.
تو ازن القوى و عدم المساو اة الكهيكلية بين الرجل

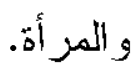
تسنخدم المنظمات الاولية مصطلح العنف القائم على نوع الجنس لوصف الأعمال الضارة التي تزتكب ضد شخص بناء على الاختلافات التي تحدد اجتماعياً بين الأكور والإنات. ورغم الجدور التاريخية للمصطلح إلا انه ماز ال يستخدم كوسيلة لتسليط الضوء على تعرض النساء و الفتيات لمختلف أشكال العنف في مواقف يتعرضن فيها للتمييز لأنهن إناث. و شتمل أمثلة العنف القائم على مولى نوع الجنس الذي يؤثر على النساء والفتيات رغم أنها لا تقتصر على: الإجهاض الانتقائي بحسب جنس الجنين وتباين فرص الحصول على الغذاء و الخدمات، والاستغلال والاعتداء الجنسي، وزواج الصغيرات وختان الإناث، والتحرش الجنسي، و إساءة، وجرائم الشرف، و العنف المنزلي او العنف الذي يمارسه الشريك،، والحرمان من المير اث أو الملكية و إساءة معاملة المسنين.

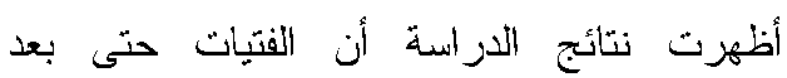
تجاوزهن لمرحلة الطفولة قد يكن عرضه لأشكال وصور من العنف الأسري تختلف باختلاف

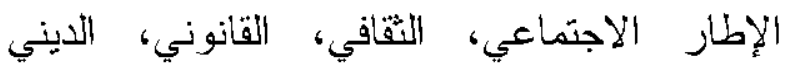
و السياسي للمجتمع. ولمفهوم القو امة ووضع الأنثى الأنى المتذني العام في المجتمع وللأسرة دور كبير في وقوع العنف عليها، كما يتعدد المعنفين بناءة على نوع العنف فالأب بسلطاته المطلقة قد يمارس 
العنف الأي يجب مناهضته، كما مازالت جرائم وممارسات العنف بحاجة لوقفة قوية ورادعة فوجود النظام لن يحمي الضحايا بشكل تلقائي مالم تقوم الجهات المعنية بما عليها من مسئوليات.. التوصيات

رغم وجود نظام الحماية من الإيذاء ولائحته

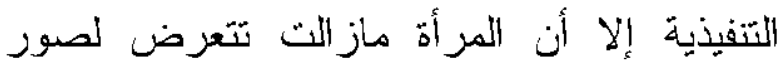
و اشكال متعددة من العنف ولذلك الخطوة الأولى الغ ألى

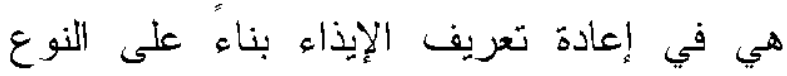

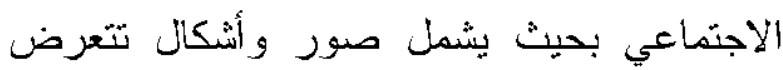

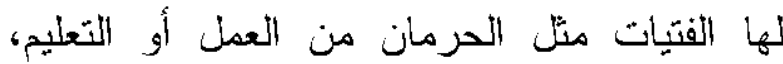

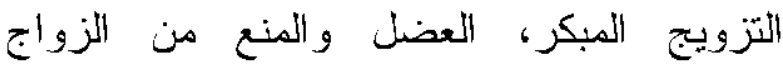
و الحرمان من الإزرث أو الز اتب. يضاف على ذلك التهن

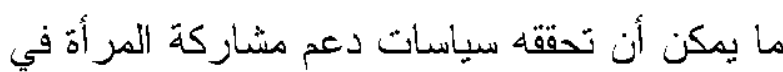

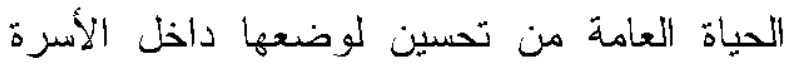

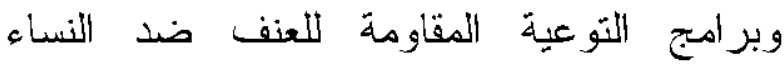
خصوصا على المستويات الرسمية ذات العلاقة بالتعامل مع جرائم العنف. أخيرا توسيع دائرة الخدمات المقدمة للمعنفات خصوصا تلك المنعلقة بالتأهيل و الاعم لمو اصلة الحياة بحيث تشمل جميع مدن ومناطق المملكة العربية السعودية.
وقد قامت المملكة العربية السعودية بسلسلة من التغييرات على مدى السنوات القليلة الماضية لتخفيف القيود المفروضة على النساء. منها تحسين الاستجابة للعنف ضد المرأة وتوفير فرص أفضل للنساء للحصول على الخدمات

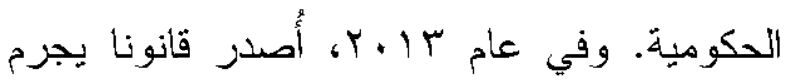

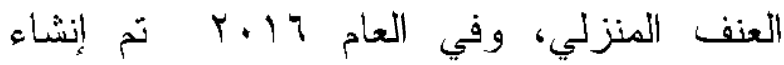

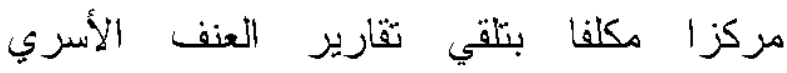
و الأستجابة له. كما عملت المملكة على تحسين

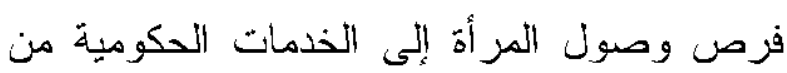

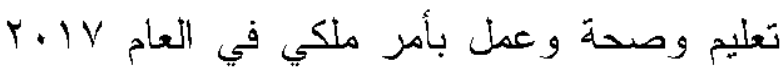

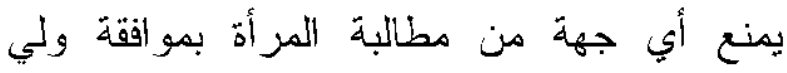

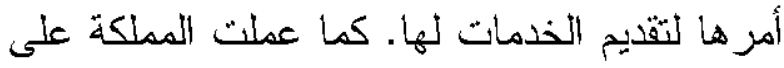

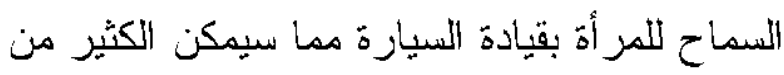
النساء من العمل و الحركة و التتقل. و وعلت المملكة ايضا على إصدار بطاقات الأسرة للنساء المطلقات و الأر امل أولا ومن ثم لجميع الأمهات

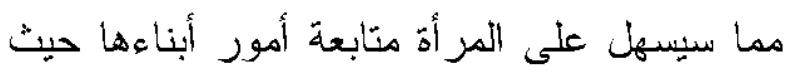

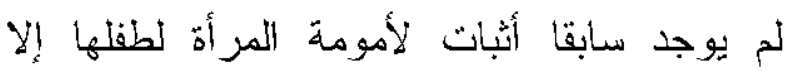

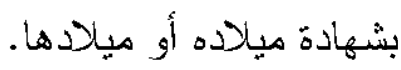

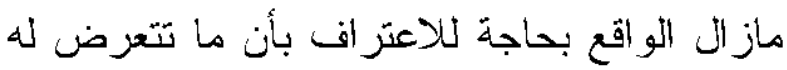
الفتيات من ممارسات هي من صور وأشكال

${ }^{1}$ Gwen Hunnicutt (2009) Varieties of Patriarchy and Violence Against Women: Resurrecting "Patriarchy" as a Theoretical Tool, Violence Against Women, Vol: 15, No: 5, pp 553-573

${ }^{2}$ Ibid, p.554

${ }^{3}$ Ibid, p. 557 
${ }^{4}$ Murray Straus and Smith (1990) Violence in Hispanic Families in the United States: Incidence rates and Structural Interpretation. In M.A Strauss and R.J. Gelles (eds) Physical Violence in the American Family (pp. 341-368) Garden City, NY: Anchor / Doubleday.

${ }^{5}$ Gelles, R.J. (1993) Through a Sociological Lens: Social Structure and Family Violence Theory. In R. J. Gelles and D.R. Loseke (eds) Current Controversies on Family Violence (pp. 31-49), London: Sage.

${ }^{6}$ Gwen Hunnicutt (2009), Ibid, p. 557-558

${ }^{7}$ Naima Tabassum, Huma Tabassum and Afzal Tabassum (2013) Social Practices Fostering Crime Against Women and the Law in Pakistan, International Research Journal of Art \& Humanities, Vol. 41, issue 41, pp 305-327

^ خمم فيها مليح (r ( ب ) وزارة الصحة: الديوان الوطني للأسرة والعمران البشري، مائدة مستديرة للنقاش حول الواقع المعاش

${ }^{9}$ Unicef.org

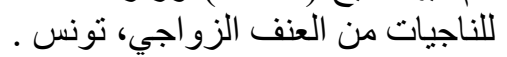

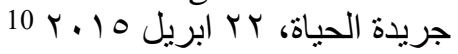

${ }^{11}$ Sanaa Al Harahsheh (2011) Sons Daughters, and Arab-American family dynamics: does a child's gender matter? Ph.D Disertations, Wayne State University.

${ }^{12}$ Ibid p. 2

${ }^{13}$ Marleau J.D \& Saucier, S. F (2002) Preference for a first-Born Boy in Western Societies, Journal of biosocial science, vol. 34, pp 13-27

14 Lundberg, S. (2006) Sons, Daughters, and Parental Behavior, Oxford Review of Economic Policy, vol. 21, No. 3, pp 1-30

${ }^{15}$ https://www.unicef.org/arabic/earlychildhood/24284_25768.html, viewed on May 18, 2018

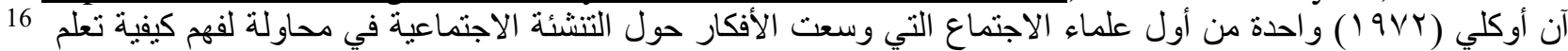

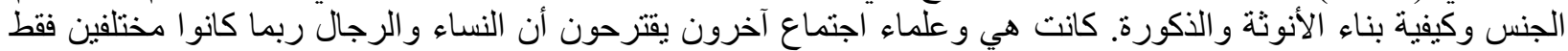

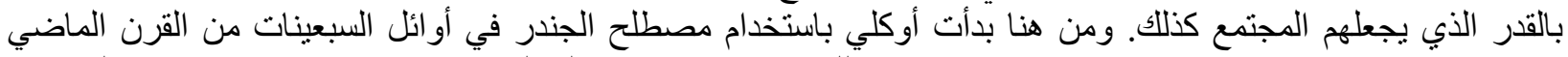

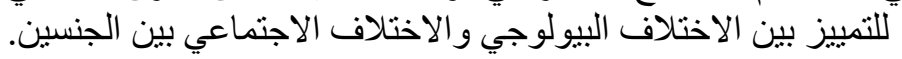

17 Un.org

${ }^{18}$ Early Marriage: child Spouses (2001) Uncief, Innocenti Digest no: 7

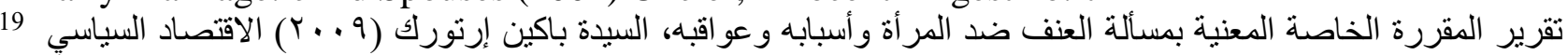

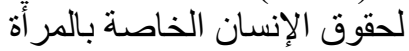

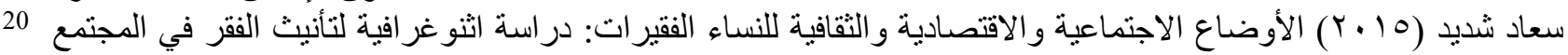

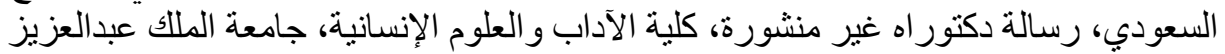

21 Nawal Nour (2009) Child Marriage: A Silent Health and Human Rights Issue, Reviews in Obstetrics \& Gynecology, vol:2, No. 1 pp 51-56

22 World Health Organization (2009) Eliminating female genital mutilation: an interagency statement.

${ }^{23}$ World Health Organization (2009) Ibdi, p.4

24 UNICEF (2005). Changing a harmful social convention: female genital mutilation/cutting. Innocent, Digest. Florence.

${ }^{25}$ WHO 2010. Female genital mutilation Fact sheets no 241.

http//www.who.int/mediacentre/facesheets/fs241/en

26 Sharmon Monagan (2010) Patriarchy: Perpetuating the Practice of Female Genital Mutilation, Journal of Alternative Perspectives in the Social Sciences, Vol 2, No 1, pp.160-181 
27 Action Plan for The Prevention of Circumcision of Girls and women 2012-2016 (FGM), Publications of the Ministry of Social Affairs and Health, Finland.

28 WHO (2008). Eliminating Female genital mutilation. An interagency statement. OHCHR, UNAIDS, UNDP, UNECA, UNESCO, UNFPA, UNHCR, UNICEF, UNIFEM, WHO. Geneva: WHO. Available at: ttp://whqlibdoc.who.int/publications/2008/978924159 6442_eng.pdf

${ }^{29}$ Action Plan for The Prevention of Circumcision of Girls and women 2012-2016 (FGM, Ibid, p. 14

${ }^{30}$ WHO (2012). Health complications of female genital mutilation. http://www.who.int/reproductivehealth/topics/fgm/health_consequences_fgm/en/index.html

31 Aysan Sev'er \& Gokcecicek Yurdakul (2001) Culture of Honor Culture of Change: A Feminist Analysis of Honor Killings in Rural Turkey, Violence Against Women, vol. 7, No. 9, pp 964-998

32 Amnesty International (2016) Culture of Discrimination: A Fact Sheet on "Honor" Killings, https://www.amnestyusa.org

${ }^{33}$ Ibid

34 Jane Haile (2007) Honour kiling Its Causes \& Consequences: Suggested Strategies For The European Parliament, A paper presented to the Human Rights Sub-Committee of the European Parliament.

35 Ibid, p. 2

${ }^{36}$ Memoona Saeed Lodhi1 \& Jawaid Ahmed Siddiqui (2014) A Sociological Perspective on the Issue of Killing In The Name of Honor in Pakistan, Journal Of Humanities And Social Science, Vol, 19, Issue 12, PP 58-61

${ }^{37}$ Eisner, M., and Ghuneim, L. (2013). Honor Killing Amongst Adolescents in Amman, Jordan. Aggressive Behavior, vol,39, pp. 405-417

38 Naima Tabassum, Huma Tabassum and Afzal Tabassum (2013) Social Practices Fostering Crime Against Women and the Law in Pakistan, International Research Journal of Art \& Humanities, Ibid

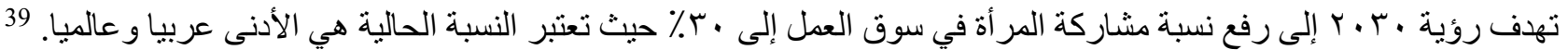

40 Williams, G. (1976). From brutality to humanity: A story of maltreatment of children. In E. Hymen \& J. Wise (eds.), Corporal punishment in American education. Temple, PA: Temple University Press.

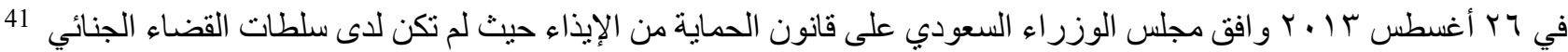

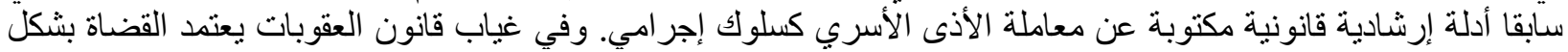

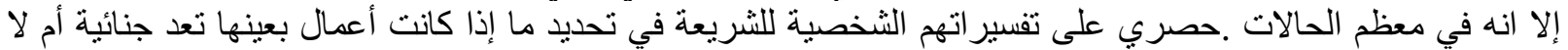

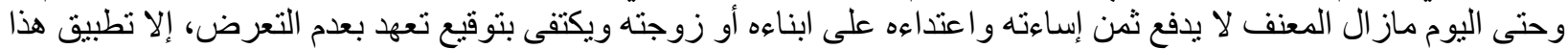

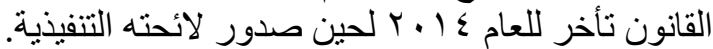

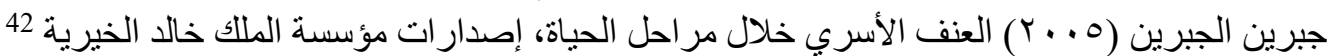

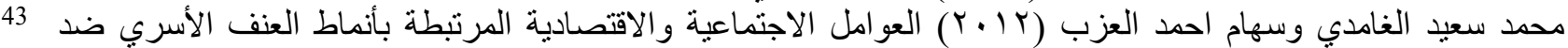

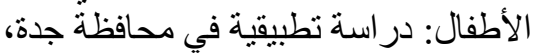

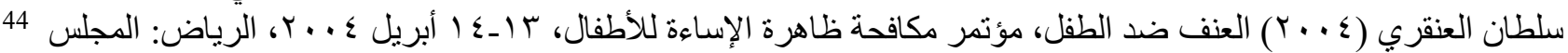
العربي للطفولة و التنمية

${ }^{45}$ Maha Almuneef, Linah Alghamdi and Hassan Saleheen, (2016) Family profile of victims of child abuse and neglect in the Kingdom of Saudi Arabia, Saudi Medical Journal, vol: 37, issue, 8, pp882-888. 
منبرة عبدالرحمن آل سعود ( ·. . ب) إيذاء الأطفال: أنواعه وأسبابة وخصائص المتعرضين له: تحديات لمهنة المخدمة 46

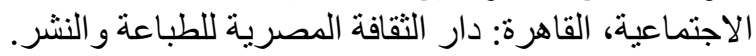

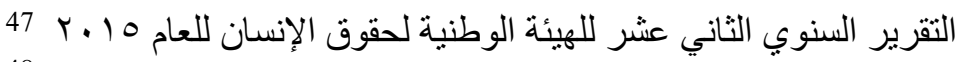

48 Nora Almosaed (2004) Violence Against Women: A Cross-Cultural Perspective, Journal of Muslim Minority Affairs, vol: 24. No. 1, pp 67-88

49 Jennifer E. Lansford and others (2010) Corporal Punishment of Children in Nine Countries as a Function of Child Gender and Parent Gender, International Journal of Pediatrics, Vol: 2010, , Article ID 672780, 12 pages

50 Shaina Greif (2010) Violence is not our Culture: the Global Campaign to stop Killing and Stoning Women, www.humanizm.net.pl/reliviol.pdf, viewed on 21.8.2017

51 A alsomari, ed. (2000) Violence In the Family, Cairo: Dar Almareefa Aljameeia.

5252 United Nations Children's Fund, A Statistical Snapshot of Violence against Adolescent Girls, UNICEF, New York, 2014.p.5

53 Ibid, p. 1

54 United Nations Children's Fund, A Statistical Snapshot of Violence against Adolescent Girls, Ibid, p.2

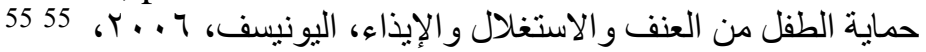

http://www.unicef.org/arabic/protection/24267_36229.html

UNICEF. Org

\title{
Violence against Girls: A Study on Gender Based Violence in Saudi Arabia
}

\author{
Nora F. Almosaed \\ Associate professor of Sociology
}




\title{
Department of Sociology and Social Work King Abdulaziz University
}

\begin{abstract}
All studies that take from violence against women as main subject for her, including western studies are focusing on violence against women in intimate relationships where the abuser is a husband or a life partner. In most MENA societies with its patriarchal culture women become victims of violence in an early age and without being in intimate relationship that is because the abuser might be the father, mother or brother.

The purpose of this study is to explore reasons and types of violence that girls might be subjected to in the Saudi society, based on information gathered from 500 college girls where most of them are in age of eighteen to twenty years old. The main findings of the study are: the majority of the respondents seemed to agree on the existence of family violence in the Saudi society and in a way that is far more than it's known. The respondents have also agreed that children regardless of their gender are the most victims of violence followed by wives and girls, $33.77 \%, 29.25 \%$ and $27.1 \%$ respectively. Fathers use violence in $37 \%$ of the cases, followed by mothers in $28 \%$ and brothers in $10 \%$ of the cases. $71 \%$ of the respondents have experienced violence as growing up and $24 \%$ are still dealing with it. As for the types of violence, girls are subjected to beatings, preventing them or threats to prevent them from education or work, sexual abuse, not taking their opinion in marriage or preventing them of marriage or marrying them in young age, verbal abuse and insults, seizure of salary or inheritance, imprisonment or prohibition of going out. Types and practices of violence that might not all or most of it are known to girls in other societies and/or harm that cannot be imagine or perceived by others.
\end{abstract}

Key Words: violence against children, violence against women, family violence, gender based violence and violence against girls. 